\title{
Interrogation and the Roberts Court
}

Jonathan Witmer-Rich

Cleveland State University, j.witmerrich@csuohio.edu

Follow this and additional works at: https://engagedscholarship.csuohio.edu/fac_articles

Part of the Constitutional Law Commons, Criminal Law Commons, and the Criminal Procedure Commons

How does access to this work benefit you? Let us know!

\section{Original Citation}

Jonathan Witmer-Rich, Interrogation and the Roberts Court, 63 Florida Law Review 1189 (2011)

This Article is brought to you for free and open access by the Faculty Scholarship at EngagedScholarship@CSU. It has been accepted for inclusion in Law Faculty Articles and Essays by an authorized administrator of EngagedScholarship@CSU. For more information, please contact research.services@law.csuohio.edu. 


\section{HEINONLINE}

Citation: 63 Fla. L. Rev. 11892011

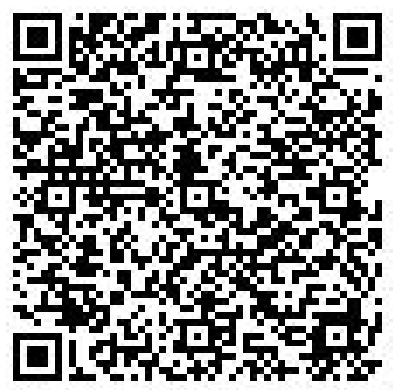

Content downloaded/printed from

HeinOnline (http://heinonline.org)

Thu Dec 5 21:45:41 2013

-- Your use of this HeinOnline PDF indicates your acceptance of HeinOnline's Terms and Conditions of the license agreement available at http://heinonline.org/HOL/License

-- The search text of this PDF is generated from uncorrected OCR text.

-- To obtain permission to use this article beyond the scope of your HeinOnline license, please use:

https://www.copyright.com/ccc/basicSearch.do?

\&operation $=$ go\&search $T y p e=0$

\&lastSearch $=$ simple\&all=on\&titleOrStdNo=1045-4241 


\title{
INTERROGATION AND THE ROBERTS COURT
}

\author{
Jonathan Witmer-Rich ${ }^{*}$
}

\begin{abstract}
Through 2010, the Roberts Court decided five cases involving the rules for police interrogation under the Fifth and Sixth Amendments: Kansas v. Ventris; Montejo v. Louisiana; Florida v. Powell; Maryland v. Shatzer; and Berghuis v. Thompkins. This Article argues that these decisions show the Roberts Court reshaping constitutional interrogation rules according to a new (as-yet unarticulated) principle: "fair play" in interrogations. The Warren Court believed that suspects in police interrogation were vulnerable to inherent compelling pressures; the Court correspondingly created procedural interrogation rules under the Fifth and Sixth Amendments (Miranda and Massiah) to protect suspects. The Roberts Court does not share that motivating concern. But rather than overruling Miranda and Massiah, the Court is reanimating those doctrines according to the new principle of "fair play" in interrogations. This "fair play" rubric presupposes interrogation suspects who are autonomous agents, expected to know and protect their rights.

Part I describes how the Roberts Court's Fifth Amendment decisions are best explained by the new rubric of "fair play" in interrogations. Part II does the same for the Court's Sixth Amendment decisions. Part III evaluates this new "fair play" rubric, concluding that it is not a fair and adequate principle for organizing constitutional interrogation doctrine. While the Warren Court's specific rules and remedies for interrogation law have been criticized over the years from both the left and the right, its underlying premise-that suspects facing police interrogation are vulnerable to abuse and overreaching - has proven robust and continues to find support in decades of empirical work. The Roberts Court's presumption that suspects in interrogation are autonomous agents capable of protecting their own interests is wrong. The resulting rules of "fair play" in interrogation fail to adequately protect the constitutional right against self-incrimination and the guarantee of the assistance of counsel in all criminal cases.
\end{abstract}

INTRODUCTION 1190

* Assistant Professor of Law, Cleveland-Marshall College of Law, Cleveland State University; J.D., University of Michigan School of Law; B.A., Goshen College. Thanks to Joel Finer, Harvey Gee, Melissa Hamilton, Cynthia Lee, Nancy Leong, John Plecnik, Milena Sterio, George C. Thomas III, Charles D. Weisselberg, and the participants in the Ohio Legal Scholarship Workshop for their very helpful feedback on drafts of this Article. Thanks to Maria Witmer-Rich for her unending support and encouragement. 
I. CHANGING RULES FOR FIFTH AMENDMENT INTERROGATION: Providing "FAIR NOTICE," Not DisPelling COERCION

A. Florida v. Powell and Berghuis v. Thompkins:

Transforming Miranda into a "Fair Notice" Right.

1. Florida v. Powell .

2. Berghuis v. Thompkins

3. Miranda Is Now About "Fair Notice," Not Dispelling Coercion

B. Maryland v. Shatzer: Miranda's Expiration Date and a New Prophylactic Antibadgering Rule

II. RESHAPING RULES FOR SIXTH AMENDMENT INTERROGATION: "FAIR PLAY" FOR BOTH DEFENDANTS AND PROSECUTORS

A. Kansas v. Ventris: "Fair Play," Impeaching a Defendant's Testimony, and Statements Obtained in Violation of the Sixth Amendment....

1. Massiah Is Not a Prophylactic Rule, and Massiah

Violations Occur at the Time of Uncounseled Interrogation.

2. "Fair Play" in Interrogation and Prosecution

B. Montejo v. Louisiana: After Erasing Michigan v.

Jackson, a Blank Slate Remains

1. Of "Fair Play" and Badgers: Preventing Police from Asking Suspects to Give Up Previously Invoked Rights

2. New Rules for "Fair Play" in Sixth Amendment Interrogation Law: Thompkins Will Apply, but Shatzer Will Not

a. Sixth Amendment Waivers: Thompkins Will Apply

b. Sixth Amendment Invocations: Shatzer Should Not Apply

III. ThE "FAIR Play" MODEL: FAULTy PREMISES MAKE FOR BAD DOCTRINE

CONCLUSION 1243

\section{INTRODUCTION}

In the first five years since Chief Justice John G. Roberts, Jr. assumed his duties on September 29, 2005, the Supreme Court issued five decisions involving constitutional limitations on police 
interrogation: Kansas v. Ventris; ${ }^{1}$ Montejo v. Louisiana, ${ }^{2}$ Florida v. Powell; ${ }^{3}$ Maryland v. Shatzer; ${ }^{4}$ and Berghuis v. Thompkins. ${ }^{5}$ All five decisions limit the protections for interrogation suspects and broaden police interrogation powers, under either the Fifth Amendment or the Sixth Amendment. ${ }^{6}$ While the ongoing erosion of the Warren Court's interrogation protections is nothing new, ${ }^{7}$ these five decisions show the Roberts Court reshaping interrogation law based on a new underlying principle: "fair play."

The purpose animating the Warren Court's interrogation rules was to

1. 129 S. Ct. 1841 (2009).

2. 129 S. Ct. 2079 (2009).

3. 130 S. Ct. $1195(2010)$.

4. 130 S. Ct. $1213(2010)$.

5. 130 S. Ct. $2250(2010)$.

6. The Roberts Court also decided one statutory interrogation decision, Corley $v$. United States, 129 S. Ct. 1558 (2009). In Corley, the only defense win of the Roberts Court interrogation cases, the Court decided that Congress intended to limit, but not eliminate, the McNabb-Mallory rule: that "an arrested person's confession is inadmissible if given after an unreasonable delay in bringing him before a judge." Id. at 1562 (citing McNabb v. United States, 318 U.S. 332 (1943), and Mallory v. United States, 354 U.S. 449 (1957)). As a statutory interpretation case, Corley is subject to modification by Congress. Moreover, the majority opinion is squarely aimed at achieving Congress's intent in 18 U.S.C. $\S 3501$ (2006), and it does not reveal much about the Justices' underlying theories of constitutional interrogation rules.

Notably, all five Roberts Court constitutional interrogation decisions were issued in the 2009 or 2010 terms, after Justice Alito assumed his duties on January 31, 2006. Thus, all five decisions were issued under the watch of the present "conservative" wing of the Roberts Court-Justices Scalia, Thomas, Roberts, and Alito-along with swing vote Justice Kennedy. Justice Sotomayor assumed office on August 8, 2009, replacing Justice Souter. Justice Souter participated in all of the 2009 decisions: Corley (majority opinion written by Justice Souter), Ventris, and Montejo. Justice Sotomayor participated in all of the 2010 decisions: Powell, Shatzer, and Thompkins. Justices Stevens, Ginsburg, and Breyer participated in all six decisions. Justice Stevens was the only justice who did not join the majority in any of the five constitutional interrogation decisions. Justice Kagan replaced Justice Stevens in the fall of 2010, after the Roberts Court's 2009-2010 interrogation decisions were handed down.

On June 16, 2011, the Court decided J.D.B. v. North Carolina, No. 09-11121 (2011), holding that when police interrogate a minor child, that child's age properly influences the question of whether that child is in "custody" for Miranda purposes. Because J.D.B. was decided while this article was being prepared for printing, this Article does not include J.D.B. in its analysis.

7. See, e.g., Arthur J. Goldberg, Escobedo and Miranda Revisited, 18 AKRON L. REv. 177, 180 (1984) (arguing "that the Court is determined to limit or overrule Miranda by erosion"); Leslie A. Lunney, The Erosion of Miranda: Stare Decisis Consequences, 48 CATH. U. L. REV. 727, 727-28 (1999) (arguing that the Court has "pretend[ed] to abide by Miranda while eviscerating its substance"); Charles J. Ogletree, Are Confessions Really Good for the Soul?: A Proposal to Mirandize Miranda, 100 HARV. L. REV. 1826, 1841 (1987) ("Although the Court as yet has given no indication that it is willing to take the more controversial step of overruling Miranda, it has deeply eroded the foundation of the doctrine, leaving Miranda almost useless in its present application."). 
protect vulnerable suspects from overbearing police pressures during interrogation. ${ }^{8}$ The Roberts Court decisions pay lip service to that concern but cannot really be explained by it. For some time now, commentators have observed that the Supreme Court instead seems to be shaping interrogation law to facilitate the admission of custodial confessions, by creating "safe harbor" rules that are relatively clear and simple for police to satisfy. ${ }^{9}$ Miranda $v$. Arizona' ${ }^{10}$ original motivating purpose-protecting vulnerable suspects-appears to have entirely vanished, prompting a number of academic-style funerals for Miranda. ${ }^{11}$ The five Roberts Court interrogation decisions seem to continue this trend.

But while the Roberts Court continues the trend of draining Miranda and its sister decision, Massiah v. United States, ${ }^{12}$ of their original motivating impetus, it has not overtly abolished or overruled these doctrines. On the contrary, the Court continues to reaffirm the ongoing vitality of Miranda and Massiah. ${ }^{13}$ If the original spirit of constitutional interrogation law has been drained away, what new spirit now animates the doctrinal corpus? Each of the five Roberts Court interrogation decisions involves a different area of interrogation law, and none on its

8. The landmark Warren Court interrogation decisions-most notably Miranda $v$. Arizona, 384 U.S. 436 (1966) and its progeny, but also Massiah v. United States, 377 U.S. 201 (1964) and its progeny-created a regime of Fifth and Sixth Amendment interrogation rules founded on the view that criminal suspects undergoing police interrogation faced serious pressures that threatened to "exact[] a heavy toll on individual liberty and trade[] on the weakness of individuals[,]" Miranda, 384 U.S. at 455, which is "destructive of human dignity." Id. at 457. The Court's decisions were accordingly motivated by a desire to "dispel the compulsion inherent in custodial surroundings." Id. at 458.

9. See Charles Fried, Order and law: arguing the Reagan Revolution-A FIRSTHAND ACCOUNT 45 (1991) ("[M]ost professional law-enforcement organizations had learned to live with Miranda, and even to love it, to the extent that it provided them with a safe harbor...."); Susan R. Klein, Identifying and (Re)Formulating Prophylactic Rules, Safe Harbors, and Incidental Rights in Constitutional Criminal Procedure, 99 MiCH. L. REv. 1030, 1033 (2001) (" $[\mathrm{A}]$ 'constitutional safe harbor rule' is a judicially created procedure that, if properly followed by the government actor, insulates the government from the argument that the constitutional clause at issue was violated.").

10. 384 U.S. 436 (1966).

11. Barry Friedman, The Wages of Stealth Overruling (with Particular Attention to Miranda v. Arizona), 99 GEO. L.J. 1, 24 (2010) ("Miranda has effectively been overruled."); Sandra Guerra Thompson, Evading Miranda: How Seibert and Patane Failed to "Save" Miranda, 40 VAL. U. L. REv. 645, 647 (2006) ("Seibert and Patane represent the coup de grace for the demise of Miranda."); Charles D. Weisselberg, Mourning Miranda, 96 CAL. L. REv. 1519,1521 (2008) ("Miranda is largely dead.").

12. 377 U.S. 201 (1964).

13. Most notably, the Court declined the chance to overnule Miranda in Dickerson v. United States, 530 U.S. 428, 432 (2000). The five decisions discussed herein do not suggest Miranda will be overruled; on the contrary, some discuss the many Miranda protections that remain in force. See, e.g., Montejo v. Louisiana, 129 S. Ct. 2079, 2090 (2009). 
face claims to be interconnected by any unifying theme. But all five can be explained by a single, unacknowledged principle: "fair play" in interrogation.

The Roberts Court's principle of "fair play" treats suspects as autonomous, empowered individuals who possess the knowledge and wherewithal to assert and protect their rights and interests. A suspect who police interrogate must receive "fair notice" of his rights, but not much more (Powell and Thompkins). A charged, represented defendant must not be unfairly deprived of the equalizing protections of counsel in interrogations, but the defendant also will not be permitted to unfairly game the system by taking the stand at trial and testifying in conflict with an earlier statement (Ventris). A willing suspect will not be protected from (often unwisely) talking to the police, but a suspect will be entitled to protection from excessive "badgering" by police once she has made clear her desire to assert her rights (Shatzer and possibly Montejo).

The spirit that animated the Warren Court's decisions in Miranda and Massiah-protecting vulnerable suspects from police coercionhas died. But the name and mantle of Miranda and Massiah live on, with a still central place in constitutional interrogation law. The Roberts Court is reanimating Miranda and Massiah with a new and wholly different spirit: creating rules for "fair play" in interrogation that facilitate the admissibility of custodial confessions at trial. The death of a sovereign monarch prompts the proclamation, "The king is dead! Long live the king!"-a recognition that the royal mantle survives the death of its holder and the name "king" becomes animated by a new person. ${ }^{14}$ The same proclamation fits this moment of constitutional transition, in which the original spirit of Miranda is gone but a new spirit now animates it: Miranda is dead! Long live Miranda! $!^{15}$

Parts I and II are descriptive. Part I addresses the three Fifth Amendment decisions-Powell, Thompkins, and Shatzer-and explains how each decision reflects the principle of "fair play" in interrogation. Part II does the same for the Sixth Amendment decisions-Montejo and Ventris. After Montejo's overruling of Michigan v. Jackson, ${ }^{16}$ Sixth Amendment interrogation law features many new, open questions. Part II thus also predicts some of the future terrain of Sixth Amendment

14. The origin of the phrase is French: Le roi est mort! Vive le roil, which appears at least as early as 1611 , in a French manual of legal maxims. See RaLPH E. GEISEY, THE RoYaL FUneral CEREMONY IN RENAISSANCE FranCE 182 (1960). The declaration signifies "the idea that, though the physical body of the king may die . . kingship is eternal." DAVID POTTER, A HiSTORY OF FRANCE, 1460-1560: THE EMERGENCE OF A NATION STATE 42 (1995).

15. Like observers of a transition in the monarchy, we might proclaim this in joy and celebration, in fear and mourning, or with mixed emotions, depending on our opinions about the passing regime as compared to its successor.

16. 475 U.S. 625 (1985). 
interrogation law, using the principle of "fair play."

Part III evaluates whether "fair play" in interrogations, as reflected in the Roberts Court decisions, is indeed a fair and adequate principle for organizing constitutional interrogation doctrine. I conclude that it is not. The Warren Court's decisions creating specific rules and remedies for interrogation law have been heavily criticized from both the right and the left. ${ }^{17}$ But the underlying premise-that suspects facing police interrogation are vulnerable to abuse and overreaching - has proven robust and continues to find support in decades of empirical work. The Roberts Court's presumption that a suspect in interrogation is an autonomous agent capable of protecting his interests is wrong. The resulting rules based on "fair play" in interrogation fail to adequately protect the constitutional right against self-incrimination and the guarantee of the assistance of counsel in all criminal cases.

\section{CHANGING RULES FOR FifTH AMENDMENT INTERROGATION: Providing "FaIR Notice," NOT DisPElling COERCION}

The Roberts Court issued three Fifth Amendment interrogation decisions, one touching on each of the three central components of the Miranda regime: warnings (Florida v. Powell), waivers (Berghuis $v$. Thompkins), and invocations (Maryland v. Shatzer). In Florida $v$. Powell, the Court continued its pattern of permitting Miranda warnings that put a suspect on notice of his basic rights to silence and counsel, even though those warnings do not track Miranda's language exactly and may not fully inform a suspect of every aspect of those rights. The Court is satisfied so long as suspects receive "fair notice" of their rights, regardless of whether suspects are actually empowered by that notice or whether the coercive interrogation atmosphere is meaningfully dispelled.

In Berghuis v. Thompkins, the Court effectively eliminated the

17. Some have criticized from the right that Miranda was constitutionally unjustified and is too costly. See, e.g., JosEPH D. GRANO, Confessions, TRUTH, AND THE LAW 199-222 (1993); Ronald J. Allen, Miranda's Hollow Core, 100 Nw. U. L. REv. 71, 73 (2006); Paul G. Cassell, Miranda's Social Costs: An Empirical Reassessment, 90 Nw. U. L. REV. 387, 391 (1996); Paul G. Cassell \& Richard Fowles, Handcuffing the Cops? A Thirty-Year Perspective on Miranda's Harmful Effects on Law Enforcement, 50 STAN. L. REV. 1055, 1060 (1998); Joseph D. Grano, Prophylactic Rules in Criminal Procedure: A Question of Article III Legitimacy, 80 Nw. U. L. REV. 100, 153 (1986). Others have criticized from the left that the Warren Court correctly diagnosed the problem but prescribed an inadequate and ineffective set of rules to remedy it. See, e.g., Richard A. Leo, Questioning the Relevance of Miranda in the Twenty-First Century, 99 MiCH. L. REv. 1000, 1026-27 (2001); George C. Thomas III, Miranda's Illusion: Telling Stories in the Police Interrogation Room, 81 TEx. L. REV. 1091, 1092, 1103-04 (2003) (reviewing Welsh S. White, Miranda's Waning Protections: Police Interrogation PrACTICES AFTER DICKERSON (2001)) ("[B]y most accounts, Miranda has been a spectacular failure."). 
"affirmative waiver" requirement from Miranda. As in Powell, the Court spent little effort ensuring that the coercive effects of custodial interrogation are dispelled; instead, the Court put the onus on suspects to protect themselves once they have received "fair notice" of their interrogation rights.

In Maryland $v$. Shatzer, the Court limited how long a suspect's Miranda invocation of the right to counsel lasts: the invocation now lasts fourteen days after release from Miranda custody. Of the three cases, Shatzer speaks most in Miranda's language of dispelling potential coercion. Shatzer, in particular, recognized the danger in police "badgering" a suspect to give up her rights after the suspect has initially asserted them. Somewhat remarkably for a Court seemingly intent on weakening what it has called the Warren Court's "prophylactic" rules-rules the Court has said are not part of the Constitution itself but which are designed to preventatively protect against violations of constitutional rights-the Shatzer Court created a new fourteen-day "prophylactic" rule to satisfy its antibadgering concern. Only Justice Clarence Thomas, partly concurring, would eliminate even this protection.

Taken together, these three decisions illustrate the emerging shape of the Fifth Amendment's interrogation rules when reformulated to reflect "fair play" in interrogation.

\section{A. Florida v. Powell and Berghuis v. Thompkins: Transforming Miranda into a "Fair Notice" Right}

While Powell and Thompkins relate to different aspects of the Miranda regime, both decisions reflect a broader theme: a Court unconcerned with protecting vulnerable suspects from the pressures of custodial interrogation and satisfied so long as police give a suspect "fair notice" of his rights.

\section{Florida v. Powell}

In Florida v. Powell, the first interrogation case of the Roberts Court's October 2009 term, the Court continued its pattern of approving Miranda warnings that deviate from the precise language articulated in Miranda itself, a trend bemoaned by many commentators, ${ }^{18}$ with

18. See, e.g., Gerald G. Ashdown, Drugs, Ideology, and the Deconstitutionalization of Criminal Procedure, 95 W. VA. L. REv. 1, 47 (1992) ("To the extent that Prysock and Eagan are utilized, either intentionally or inadvertently, the effectiveness of Miranda as an insulator is undercut."); Paul Marcus, A Return to the "Bright Line Rule" of Miranda, 35 WM. \& MARY L. REv. 93, 129 (1993) ("No deviation from Miranda should be allowed unless the government clearly can demonstrate that the deviation would not lead to confusion regarding the required warnings, a difficult burden to sustain and certainly one that the government could not have sustained in either Prysock or Duckworth."); Irene Merker Rosenberg \& Yale L. Rosenberg, A 
apparently little effect on the Court. ${ }^{19}$ The Court had previously approved variations from the exact language of Miranda in California $v$. Prysock ${ }^{20}$ and Duckworth v. Eagan. ${ }^{21}$ Those decisions, Justice Ruth Bader Ginsburg wrote, "inform our judgment here" in Powell. ${ }^{22}$

In Prysock, the "officer informed the suspect of his right to a lawyer's presence during questioning and his right to counsel appointed at no cost," but did not explain "that the appointment of an attorney would occur prior to the impending interrogation." 23 The Court held that these warnings were constitutionally sufficient, as the warnings did not suggest "any limitation on the right to the presence of appointed counsel." ${ }^{, 24}$ In Duckworth, the officer informed the suspect of the right to counsel during the interrogation and the right to an appointed attorney, but added that the attorney would be appointed "if and when you go to court." ${ }^{, 25}$ The Court, noting that this statement accurately described the procedure under state law (a lawyer would first be appointed at the first court appearance), held that this addition "simply anticipates [a] question" the suspect may well ask. ${ }^{26}$ Again, the Court held the warning was constitutionally sufficient.

In the wake of Prysock and Duckworth, a circuit split developed on one particular feature of the Miranda warning: whether the warning needed to inform the accused that he not only had a right to counsel, but that he had a right to counsel during police questioning. Before Powell,

Modest Proposal for the Abolition of Custodial Confessions, 68 N.C. L. REV. 69, 88 (1989) ("[A]fter Duckworth, the warnings designed to advise defendants of their rights may instead be used to mislead them and to induce ignorant waivers."); Thompson, supra note 11, at 657 (stating that cases like Prysock or Duckworth "have indeed turned Miranda's 'safeguards' into a minor formality that is not likely to impede the path to interrogation and may in fact be a useful interrogation tool" (quoting Michigan v. Tucker, 417 U.S. 433, 444 (1974))); Michael L. Scheier, Case Note, Miranda Warnings and Habeas Corpus: The Supreme Court's Erosion of Prisoners' Fifth Amendment Rights in Duckworth v. Eagan, 109 S. Ct. 2875 (1989), 59 U. CIN. L. REv. 261, 282 (1990). But see Eugene R. Milhizer, Rethinking Police Interrogation: Encouraging Reliable Confessions While Respecting Suspects' Dignity, 41 VaL. U. L. REv. 1, 97-98 (2006) (proposing a revised Miranda warning and relying on Prysock and Duckworth as support for the flexibility the Court has allowed in formulating Miranda warnings); Lawrence Rosenthal, Against Orthodoxy: Miranda Is Not Prophylactic and the Constitution Is Not Perfect, 10 CHAP. L. REv. 579, 598 (2007) (defending Prysock and Duckworth as consistent with the point that "any advice that enables a suspect to make a knowing and intelligent decision about Fifth Amendment rights will comport with constitutional standards").

19. The Powell majority does not cite or address any of the academic criticism of its past decisions in this area.

20. 453 U.S. $355,355-56$ (1981) (per curiam).

21. 492 U.S. 195, 200-01 (1989).

22. Florida v. Powell, 130 S. Ct. 1195,1204 (2010).

23. Id. (citing Prysock, 453 U.S. at 356-59).

24. Prysock, 453 U.S. at $360-61$.

25. Duckworth, 492 U.S. at $197-98$.

26. Id. at 204. 
"[t]he Fifth, Sixth, Ninth, and Tenth Circuits ... interpreted Miranda to require an explicit warning of the right to have counsel present during questioning." 27 In contrast, "the Second, Fourth, Seventh, and Eighth Circuits [did] not require the police to explicitly inform the suspect of his right to have counsel present during the interrogation to satisfy Miranda requirements." 28 Commentators urged the Supreme Court to resolve this issue, and the Court did so in Powell. ${ }^{29}$

In Powell, the officers informed Powell that he had "the right to talk to a lawyer before answering any ... questions," that if he could not afford a lawyer, "one [would] be appointed for [him] without cost and before any questioning[,]" and that he had "the right to use any of these rights at any time [he] want[ed] during this interview." ${ }^{30}$ The Court, in a 7-2 opinion by Justice Ginsburg, held that these warnings "reasonably conveyed Powell's right to have an attorney present, not only at the outset of interrogation, but at all times." 31

In Powell, as in Prysock and Duckworth, the Court did not narrow the substance of the warnings required by Miranda. For example, the Court did not hold that the warnings need not convey the suspect's right to have counsel present "during the interrogation." Instead, the Court reiterated that "[t]he four warnings Miranda requires are invariable," but the specific words required to convey that "essential information"

27. Daria K. Boxer, Comment, Miranda with Precision: Why the Current Circuit Split Should Be Solved in Favor of a Uniform Requirement of an Explicit Miranda Warning of the Right to Have Counsel Present During Interrogation, 37 Sw. U. L. REV. 425, 425 (2008) (citing United States v. Tillman, 963 F.2d 137, 140-42 (6th Cir. 1992); United States v. Noti, 731 F.2d 610, 615 (9th Cir. 1984); United States v. Anthon, 648 F.2d 669, 672-74 (10th Cir. 1981); Atwell v. United States, 398 F.2d 507, 510 (5th Cir. 1968)).

28. Id. at 425-26 (citing United States v. Frankson, 83 F.3d 79, 81-82 (4th Cir. 1996); United States v. Caldwell, 954 F.2d 496, 501-04 (8th Cir. 1992); United States v. Adams, 484 F.2d 357, 361-62 (7th Cir. 1973); United States v. Vanterpool, 394 F.2d 697, 698-99 (2d Cir. 1968)).

29. Before Powell, some commentators urged the Court to resolve the split by requiring an explicit warning of the right to counsel during police interrogation. See Adam S. Bazelon, Comment, Adding (or Reaffirming) a Temporal Element to the Miranda Warning "You Have the Right to an Attorney," 90 MARQ. L. REV. 1009, 1010 (2007) (arguing "that both the Fifth Amendment and Miranda dictate that a suspect must be explicitly made aware of the right to have an attorney present during interrogation"); Boxer, supra note 27, at 426 ("An explicit warning of the right to have an attomey present during the actual interrogation is essential to the proper functioning of the Miranda safeguards ...."). Others argued that "a suspect's confession [should] not be excluded from evidence merely because police fail to expressly inform him of his right to have counsel present during police questioning." Derek Bottcher, Note, Bridgers v. Dretke: Not Everything You Say Can and Will Be Used Against You, 18 Geo. MAson U. C.R. L.J. 359, 387 (2008).

30. Florida v. Powell, 130 S. Ct. 1195, 1200 (2010) (quoting Joint Appendix at 3, Powell, 130 S. Ct. 1195 (No. 08-1175)).

31. Id. at 1205 . 
are not. ${ }^{32}$ The Court held that Miranda did require a warning that "reasonably conveyed" to the suspect the right to have counsel present during the interrogation, but also held that Florida's warning - which did not explicitly so state-communicated [that] same essential message., 33

One of the most notable features of the Powell opinion is the absence of any reference to the growing body of empirical research on suspects' poor comprehension of various versions of Miranda warnings. Professor Charles D. Weisselberg, noting the Court's trend of approving variations on Miranda warnings without regard to "whether officers phrased them in language that defendants can really understand[,]" recently concluded that " $[t]$ he best evidence is now that a significant percentage of suspects simply cannot comprehend the warnings or the rights they are intended to convey. ${ }^{34}$ In the Powell litigation, a number of briefs in support of Respondent Powell pointed the Court directly to this evidence; for instance, the amicus brief of the Florida Association of Criminal Defense Lawyers relied heavily on studies showing the relatively poor literacy and comprehension skills of criminal suspects, as well as studies showing relatively poor levels of comprehension of Miranda rights. That amicus brief noted that since Miranda, "numerous studies have examined whether criminal defendants are, in fact, understanding their Miranda rights." 35 The brief also noted that "the one conclusion on which all of the studies agree is that the clarity of Miranda warnings matters." 36

The Supreme Court did not dispute the quality of these studies, discuss other reasonable inferences to be drawn from them, or explain them away in some other fashion. Instead, the Court disregarded the studies entirely. The Court's failure to cite or discuss these empirical studies suggests that the Court is not primarily interested in whether suspects actually comprehend the substance of the Miranda warnings. Instead, as discussed at greater length below, the Court is simply trying to ensure that suspects receive "fair notice" of their rights, without concerning itself with whether that notice actually dispels any inherent

32. Id. at 1204 .

33. Id. at $1205-06$.

34. Weisselberg, supra note 11 , at 1563-64.

35. Brief for the Florida Ass'n of Criminal Defense Lawyers as Amicus Curiae Supporting Respondent at 6, Powell, $130 \mathrm{~S}$. Ct. 1195 (No. 08-1175) (citing Richard Rogers, $A$ Little Knowledge Is a Dangerous Thing . . Emerging Miranda Research and Professional Roles for Psychologists, 63 AM. PsychOLOGIST 776, 777 (2008); Richard Rogers et al., An Analysis of Miranda Warnings and Waivers: Comprehension and Coverage, 31 LAW \& HuM. BEHAV. 177, 178-79 (2007); and Richard Rogers et al., The Language of Miranda Warnings in American Jurisdictions: A Replication and Vocabulary Analysis, 32 LAW \& HUM. BEHAV. 124, 125-26 (2008)).

36. Id. 
coercion in custodial interrogation.

\section{Berghuis v. Thompkins}

In Berghuis v. Thompkins, the Court addressed the "waiver" prong of Miranda, holding that "[w]here the prosecution shows that a Miranda warning was given and that it was understood by the accused, an accused's uncoerced statement establishes an implied waiver of the right to remain silent." ${ }^{, 37}$ In addition, the Court held that "after giving a Miranda warning, police may interrogate a suspect who has neither invoked nor waived his or her Miranda rights"- that is, if a suspect has not affirmatively invoked his right to remain silent, the police do not need to obtain a waiver before they begin to question the suspect. ${ }^{38}$ In these two parts of Thompkins, the Court completed the ongoing rejection of several key parts of the original Miranda decision.

In Miranda, the Court stated fairly explicitly that a suspect would have to affirmatively waive his right to silence and right to counsel before police could obtain an admissible confession. The Court stated, "a heavy burden rests on the government to demonstrate that the defendant knowingly and intelligently waived his privilege against selfincrimination and his right to retained or appointed counsel[,]" and "a valid waiver will not be presumed simply from the silence of the accused after warnings are given or simply from the fact that a confession was in fact eventually obtained."

Professor Yale Kamisar has noted that "[a]lthough ' $[\mathrm{t}]$ he tone and language of the majority opinion in Miranda seemed to indicate that the Court would be receptive to nothing short of an express waiver of the rights involved,' the post-Warren Court settled for less-far less." ${ }^{, 40}$ The Court soon began to retreat from its strong language in North Carolina $v$. Butler, ${ }^{41}$ holding that "[a]n express written or oral statement of waiver... is not inevitably either necessary or sufficient to establish waiver." ${ }^{, 42}$ The Court said, "mere silence is not enough" to waive Miranda rights, but it may be possible that "the defendant's silence, coupled with an understanding of his rights and a course of conduct indicating waiver," might "support a conclusion that a defendant has

37. 130 S. Ct. $2250,2261-62(2010)$.

38. Id. at 2264.

39. Miranda v. Arizona, 384 U.S. 436, 475 (1966).

40. Yale Kamisar, On the Fortieth Anniversary of the Miranda Case: Why We Needed It, How We Got It-And What Happened to It, 5 OHIO Sr. J. CRIM. L. 163, 180 (2007) (quoting 2 Wayne R. laFave, Jerold H. Israel \& Nancy J. King, Criminal Procedure 580 (2d ed. 1999)).

41. 441 U.S. 369 (1979).

42. Id. at 373 . 
waived his rights." ${ }^{43}$ Thompkins goes a significant step further, holding that the suspect's answer to a question-that is, the confession itself (the single word "yes" in Thompkins) ${ }^{44}$ - can constitute the "course of conduct indicating waiver" referenced in Butler. ${ }^{45}$

In the wake of Butler, commentators argued that any "affirmative waiver" requirement effectively had been eliminated. As early as 1988, Professor Mark Berger observed, "In practice, it appears that as long as the warnings are given and the suspect exhibits no overt signs of a lack of capacity to understand them, his waiver will be upheld.",46 Professor George C. Thomas III reaffirmed this description more recently. Based on his "reading [of] hundreds of appellate opinions deciding whether the police complied with Miranda[,]" he concludes that "once the prosecutor proves that the warnings were given in a language that the suspect understands," courts find a Miranda waiver if "the suspect answered police questions after saying that he understood the warnings." 47 From my point of view as a criminal defense lawyer from 2006 through 2009, there was a bit more left of the "waiver" requirement in those years than Berger and Thomas claim, although it is certainly true that Butler had significantly eased the prosecutor's burden. A case like Thompkins, in which the defendant had not said anything remotely resembling a waiver before confessing, would have been subject to a robust suppression motion. The admissibility of the confession would have been uncertain, and there is a good chance the prosecutor would have offered a favorable plea bargain to avoid litigating the issue. ${ }^{48}$ But that is now a historical debate. After Thompkins, Thomas's description of Miranda "practice" is now formally a part of the Court's black-letter law: "Where the prosecution shows that a Miranda warning was given and that it was understood by the accused, an accused's uncoerced statement establishes an implied waiver of the right to remain silent.",49

In Thompkins, police in Ohio arrested Van Chester Thompkins, a suspect in a shooting that had occurred about a year earlier in

43. Id.

44. Berghuis v. Thompkins, 130 S. Ct. 2250, 2257 (2010).

45. Id. at 2263 (quoting Butler, 441 U.S. at 373) (internal quotation marks omitted).

46. Mark Berger, Compromise and Continuity: Miranda Waivers, Confession Admissibility, and the Retention of Interrogation Protections, 49 U. PITT. L. REV. 1007, 1063 (1988).

47. George C. Thomas III, Separated at Birth but Siblings Nonetheless: Miranda and the Due Process Notice Cases, 99 MicH. L. REv. 1081, 1082 (2001).

48. The Sixth Circuit's decision in Thompkins is one example that the waiver requirement still retained some vitality. In the decision reversed by the Supreme Court, the Sixth Circuit had held that Thompkins had not waived his Miranda rights and thus was entitled to habeas relief. Thompkins v. Berghuis, 547 F.3d 572 (6th Cir. 2008), rev'd, 130 S. Ct. 2250 (2010).

49. Thompkins, $130 \mathrm{~S}$. Ct. at 2262. 
Southfield, Michigan. Southfield police arrived in Ohio and interrogated Thompkins for about three hours, starting around 1:30 p.m. The officers presented Thompkins with a Miranda form, had him read one of the warnings aloud, and then read him the remaining warnings. ${ }^{50}$ Thompkins did not sign a waiver form, never orally stated that he would waive his rights, and never said anything along the lines of, "I will talk to you." ${ }^{.51}$ Nor did Thompkins affirmatively invoke his right to silence or right to counsel. Instead, Thompkins was "“[1]argely' silent during the interrogation," giving a "few limited verbal responses . . . such as 'yeah,' 'no,' or 'I don't know." 52 He nodded his head a few times, and once said he "'didn't want a peppermint' that was offered to him by the police and that the chair he was 'sitting in was hard.

The Court described the critical part of the interrogation as follows:

About 2 hours and 45 minutes into the interrogation, [Detective] Helgert asked Thompkins, "Do you believe in God?" Thompkins made eye contact with Helgert and said "Yes," and his eyes "well[ed] up with tears." Helgert asked, "Do you pray to God?" Thompkins said, "Yes." Helgert asked, "Do you pray to God to forgive you for shooting that boy down?" Thompkins answered "Yes" and looked away. ${ }^{54}$

Thompkins declined to make a written confession, and the interrogation ended soon after. ${ }^{55}$

In a 5-4 opinion by Justice Anthony Kennedy, the Court held that Thompkins had waived his right to remain silent. Noting Butler's holding that some "course of conduct" on the part of the suspect might indicate waiver, the Court held that Thompkins' answer "Yes" was itself enough: "Thompkins's answer to [Detective] Helgert's question about praying to God for forgiveness for shooting the victim [is] sufficient to show a course of conduct indicating waiver [of the right to remain silent]." 56

In reaching this conclusion, the Court asserted that " $[t]$ he main purpose of Miranda is to ensure that an accused is advised of and understands the right to remain silent and the right to counsel." ${ }^{57}$ Thus, instead of referring to the "inherent coercion" of custodial interrogation,

50. Id. at 2256.

51. Cf. Butler, 441 U.S. at 371 (finding a Miranda waiver for a suspect who said, "I will talk to you but I am not signing any form").

52. Thompkins, $130 \mathrm{~S}$. Ct. at 2256.

53. Id. at 2256-57.

54. Id. at 2257 (citations omitted).

55. Id.

56. Id. at 2263 .

57. Id. at 2261 . 
the majority described Miranda's purpose as informational: providing a suspect with notice of her rights. The Thompkins majority's only reference to the "inherent coercion" of the interrogation room is a quotation of Moran $v$. Burbine to the effect that the informational aspects of Miranda-delivering the warnings-fully dispel any coercion: "But 'as Miranda holds, full comprehension of the rights to remain silent and request an attorney are sufficient to dispel whatever coercion is inherent in the interrogation process."

Thompkins also argued that "even if his answer to Detective Helgert could constitute a waiver of his right to remain silent, the police were not allowed to question him until they obtained a waiver first." ${ }^{, 59}$ This argument-like the requirement of an affirmative waiver-finds good support in Miranda itself. As Charles Weisselberg noted, "The Miranda Court assumed that warnings would be given and waivers obtained prior to the start of questioning or the application of the tactics described in the Miranda opinion." ${ }^{\circ 0}$ The Thompkins Court expressly found the contrary, reasoning that "the primary protection afforded suspects subject[ed] to custodial interrogation is the Miranda warnings themselves." ${ }^{\prime 61}$ Accordingly, police must first "have given the accused a Miranda warning." 62 Once the warning has been given, however, "police may interrogate a suspect who has neither invoked nor waived his or her Miranda rights," and see whether the suspect eventually provides an "express or implied waiver." ${ }^{.63}$ Given the Court's ruling that simply answering a question after nearly three hours of questioning can itself be an implied waiver, this holding means that for a suspect who has neither waived nor invoked her rights, the police can continue to interrogate her until she confesses.

Commentators have long noted that Miranda's protective regime consists, at its core, of two elements: warnings and waivers. ${ }^{64}$ The

58. Id. at 2260 (quoting Moran v. Burbine, 475 U.S. 412, 427 (1986)). Contrast this with the dissent in Thompkins, which takes pains to emphasize that Miranda is "premised on the idea that custodial interrogation is inherently coercive," so "[r] equiring proof of a course of conduct beyond the inculpatory statements themselves is critical to ensuring that those statements are voluntary admissions and not the dubious product of an overbome will." Id. at 2272-73 (Sotomayor, J., dissenting).

59. Id. at 2263 (majority opinion).

60. Weisselberg, supra note 11 , at 1547 (emphasis added). Weisselberg added, "The Court assumed, I believe, that the 'heavy burden' to show waiver would create a 'time out' prior to interrogation, during which well-informed and unpressured suspects could decide whether to speak." Id. at 1529.

61. Thompkins, 130 S. Ct. at 2263 (quoting Davis v. United States, 512 U.S. 452, 460 (1994) (Kennedy, J., dissenting)).

62. Id. at 2264 .

63. Id.

64. Allen, supra note 17, at 74-75 (referring to "Miranda v. Arizona's substitution of a waming and waiver regime" for the due process "voluntariness" test); Kamisar, supra note 40 , 
Thompkins decision pares down that "familiar regime of warnings and waivers" ${ }^{\circ 5}$ by effectively eliminating the "waiver" requirement, which changes Miranda's protections significantly. As Yale Kamisar has noted, "if the privilege is easily waived, there is really no privilege at all." "66 In Justice Sonia Sotomayor's words, the Thompkins majority "overrules sub silentio an essential aspect of the protections Miranda has long provided for the constitutional guarantee against selfincrimination." ${ }^{67}$

\section{Miranda Is Now About "Fair Notice," Not Dispelling Coercion}

In both Powell and Thompkins, the Court displayed relative indifference to whether the defendants had genuinely escaped or overcome the inherent pressures of custodial interrogation. Rather than focus on the suspect's perspective and whether the suspect received warnings that fully ensured he comprehended his rights (Powell) and was adequately empowered to avoid questioning unless he affirmatively chose it (Thompkins), the Court focused on whether the police had provided adequate notice to the defendant of his basic rights to have a lawyer present and to remain silent. ${ }^{68}$ Both decisions reflect an ongoing reorientation of Miranda of the sort previously described by George Thomas: away from the anticoercion concern that clearly motivated the Miranda Court and toward a more pared down, due process-like "notice" function. ${ }^{69}$

Through Thompkins and Powell, the Roberts Court has continued this transformation of Miranda, showing that Miranda is no longer primarily about dispelling the inherent coercion of the interrogation room. Now, Miranda is more akin to due process, simply ensuring that "the decision of whether to answer police questions [is] up to presumably autonomous agents who have been given information about the consequences of answering., 70

at 172 (explaining that instead of "condition[ing] custodial police questioning on the presence of counsel[, Miranda] conditions it . . on the giving of certain warnings by the police and the obtaining of waivers of certain rights from custodial suspects") (emphasis added); Weisselberg, supra note 11, at 1521 ("Miranda's familiar regime of warnings and waivers was intended to afford custodial suspects an informed and unfettered choice between speech and silence and, at the same time, prevent involuntary statements.").

65. Weisselberg, supra note 11 , at 1521.

66. Yale Kamisar, Equal Justice in the Gatehouses and Mansions of American Criminal Procedure: From Powell to Gideon, from Escobedo to . . , in CRIMINAL JUSTICE IN OUR TIME 33 (A.E. Dick Howard ed., 1965) (quoting Note, The Privilege Against Self-Incrimination: Does It Exist in the Police Station?, 5 STAN. L. REV. 459, 477 (1953)).

67. Thompkins, 130 S. Ct. at 2272 (Sotomayor, J., dissenting).

68. See supra Section I.A.

69. Thomas, supra note 47 , at $1083,1087$.

70. Id. at 1106. 
Thomas argues, "Courts have transformed Miranda from a case about the Fifth Amendment privilege against self incrimination to one about due process." continued validity-may be rooted in our legal culture's assumption that Americans are "autonomous agents capable of acting in their own best interests.", This autonomy requires "at least some level of information about the consequences of conduct before one acts in a way that causes a right to be lost"-that is, it entails being informed of one's rights before choosing what to do in the interrogation room. ${ }^{73}$ Miranda, reformulated as a "fair notice" regime, leaves "the decision of whether to answer police questions up to presumably autonomous agents who have been given information about the consequences of answering., 74

Thompkins and Powell add significantly to the evidence "suggest[ing] that Miranda is not really about the Fifth Amendment privilege"- at least, not anymore. ${ }^{75}$ Instead, today,

Miranda is about fair notice that suspects have no duty to answer police questions. Once the police give that notice, the basic rationale of Miranda is satisfied and everyone is happy. The suspect gets the notice he deserves, the police get a statement, the prosecutor gets a conviction, and the appellate court will affirm (as long as the suspect understands the language in which the warnings are given). ${ }^{76}$

As the Powell Court recognized, Powell is a continuation of the Court's earlier decisions in Prysock and Duckworth ${ }^{77}$ Thomas observed that Duckworth supported his view "[t]hat Miranda is more about due process notice than neutralizing inherent compulsion."78 As noted above, the Court in Duckworth approved warnings that told suspects they had a right to a lawyer, but "[w]e have no way of giving you a lawyer, but one will be appointed for you, if you wish, if and when you go to court." ${ }^{.79}$ The danger with this warning, Thomas notes, "is that the warnings seem to promise an appointed lawyer only if the suspect is arraigned at some later time. ... [I]f the principal function of [Miranda] warnings is to dispel the inherent compulsion of police interrogation,

71. Id. at 1083 .

72. Id. at 1106 .

73. Id.

74. $I d$.

75. Id. at 1102 .

76. Id.

77. Florida v. Powell, 130 S. Ct. 1195, 1204 (2010).

78. Thomas, supra note 47, at 1107.

79. Duckworth v. Eagan, 492 U.S. 195, 198 (1989) (quoting Eagan v. Duckworth, 843 F.2d 1554, 1555-56 (7th Cir. 1988)) (internal quotation marks omitted). 
the warnings in Duckworth don't seem particularly well fitted for the job." ${ }^{, 80}$ In contrast, if "the principal idea" of the warnings "is to provide notice that a suspect does not have to answer and notice that his answers can be used against him in court, [the Duckworth] warnings work just fine." $" 81$

The same is true of Powell. If the Court were truly concerned with neutralizing the inherent compulsion of custodial interrogation, the Court should be more concerned with the substance of the warnings. In addition, the Court should be keenly interested in empirical research suggesting that many suspects misinterpret or do not understand Miranda warnings. In Powell, however, the Court ignored that research entirely.

Charles Weisselberg notes that "[a] central assumption of the Miranda Court was that suspects would understand the warnings and be able to act on them." ${ }^{82}$ When Miranda was decided, the "Court had no empirical evidence to suggest that standardized warnings would be effective." 83 By the time of Powell, however, the Court was presented with ample "evidence strongly suggest[ing] the contrary, at least for a substantial number of suspects. ${ }^{, 84}$ But the Court no longer seems to care about the effectiveness of the warning in dispelling the inherent coerciveness of custodial interrogation. Weisselberg notes that the Court's "continued and almost religious belief that any form of warning that 'covers the bases' will indeed be effective in informing suspects of their rights" seems unjustified, given the "remarkable proliferation in the variations of warnings," and the growing empirical evidence that many suspects do not fully understand Miranda warnings. ${ }^{85}$ But perhaps the answer is that dispelling coercion is not what the Court wants Miranda to do anymore.

Powell instead suggests the Court is not mainly concerned with whether most suspects have fully comprehended and appreciated the power of their interrogation rights. The Court is satisfied with the more limited goal of ensuring that police have put the defendant on notice of his rights-whether or not that notice is really understood and appreciated.

Thompkins likewise makes much more sense if one assumes the Court is interested in ensuring suspects receive "fair notice" of their rights, rather than ensuring that suspects are genuinely empowered in the custodial interrogation environment. In dissent, Justice Sotomayor

80. Thomas, supra note 47 , at $1107-08$.

81. Id. at 1108 .

82. Weisselberg, supra note 11 , at 1577.

83. Id.

84. $I d$.

85. Id. 
accused the majority of "ignor[ing] the important interests Miranda safeguards[,]" and stated the majority's decision "bodes poorly for the fundamental principles that Miranda protects. ${ }^{.86}$ Insofar as the Miranda protections were originally intended to dispel the "inherently coercive" nature of "custodial interrogation" so as to "ensur[e] [that an accused's] statements are voluntary admissions and not the dubious product of an overborne will,"87 Justice Sotomayor's criticisms are well-grounded. Indeed, the majority did little to respond to this critique, perhaps because it is true but now misplaced: Miranda is no longer primarily about dispelling the inherent coercion of the interrogation room, but now serves a due process-like "notice" function, ensuring that "the decision of whether to answer police questions [is] up to presumably autonomous agents who have been given information about the consequences of answering." $" 88$

The formal logic of the Thompkins majority opinion accepts that Miranda is about providing notice and dispelling coercion. As a practical matter, however, the majority is now willing to simply assume the latter-that any coercion is in fact dispelled-whenever adequate notice is provided. Thus, the majority says "[t]he main purpose of Miranda is to ensure that an accused is advised of and understands the right to remain silent and the right to counsel." ${ }^{\prime 89}$ Once the warnings have been provided, the majority simply assumes any inherent coercion is automatically dispelled: "as Miranda holds, full comprehension of the rights to remain silent and request an attorney are sufficient to dispel whatever coercion is inherent in the interrogation process."

The Court's other conclusion in Thompkins, that "police may interrogate a suspect who has neither invoked nor waived his or her Miranda rights," "1 also makes more sense based on the "fair notice" theory. Weisselberg, writing just before Thompkins was decided, noted that when police continue to question a suspect who has not waived his Miranda rights, "it would be difficult to continue to assume that warnings and waivers take place in an atmosphere where compelling pressures are minimized." ${ }^{92}$ It is hard to see how permitting police to

86. Berghuis v. Thompkins, 130 S. Ct. 2250, 2273 (Sotomayor, J., dissenting).

87. Id. at 2272-73.

88. Thomas, supra note 47 , at 1106.

89. Thompkins, 130 S. Ct. at 2261.

90. Id. at 2260 (quoting Moran v. Burbine, 475 U.S. 412,427 (1986)) (internal quotation marks omitted). Contrast this with the dissent, which takes pains to emphasize that Miranda is "premised on the idea that custodial interrogation is inherently coercive," so "[r]equiring proof of a course of conduct beyond the inculpatory statements themselves is critical to ensuring that those statements are voluntary admissions and not the dubious product of an overbome will." Id. at 2272-73 (Sotomayor, J., dissenting).

91. Id. at 2264 (majority opinion).

92. Weisselberg, supra note 11 , at 1563. 
interrogate a defendant who remains largely silent for three hours is consistent with an overriding concern about the inherent coercion of the interrogation room. But if the core purpose of Miranda is "fair notice," then it makes sense that once police have provided notice, they are free to question the suspect even without an affirmative waiver.

In dissent, Justice Sotomayor accused the majority of creating "a new general principle of law" that "flatly contradict[s] [the Court's] longstanding views." 93 She stated that "[r]arely do this Court's precedents provide clearly established law so closely on point with the facts of a particular case." "94 Under Miranda and Butler, courts "must presume that a defendant did not waive his right[s]," that "mere silence" in response to questioning is "not enough," be presumed 'simply from the fact that a confession was in fact eventually obtained.

The majority, struggling to distinguish Thompkins from those prior statements, drew the following fine distinction to explain implied waiver. The majority first conceded that "[i]f the State establishes that a Miranda warning was given and the accused made an uncoerced statement, this showing, standing alone, is insufficient to demonstrate 'a valid waiver' of Miranda rights." something, the majority explains, is simply the "additional showing that the accused understood these rights." shows that a Miranda warning was given and that it was understood by the accused, an accused's uncoerced statement establishes an implied waiver of the right to remain silent." 99

The key factor distinguishing an invalid waiver of the sort ruled out by Miranda and Butler-warnings and an eventual confession-from a valid waiver under Thompkins, is evidence that the warning "was understood by the accused." played by the defendant's "understanding" of his rights, what sort of "understanding" does the Court seem to have in mind? In Powell, the Court was singularly unconcerned with evidence of how persons actually comprehend and appreciate the full panoply of rights recognized by Miranda: so long as the defendant is put on notice of his basic rights, Miranda is satisfied. In Thompkins, the evidence that Thompkins "understood" his Miranda rights is rather slim. The Court

93. Thompkins, 130 S. Ct. at 2271 (Sotomayor, J., dissenting).

94. Id. at 2270 .

95. Id. (quoting North Carolina v. Butler, 441 U.S. 369, 373 (1979)) (internal quotation marks omitted).

96. Id. (quoting Miranda v. Arizona, 384 U.S. 436, 475 (1966)).

97. Id. at 2261 (majority opinion) (quoting Miranda, 384 U.S. at 475).

98. Id.

99. Id. at 2262 .

100. Id. 
only wrote in the negative: "There is no basis in this case to conclude that he did not understand his rights[,]" and "there is no contention that Thompkins did not understand his rights[.]" ${ }^{101}$ The actual "evidence" that Thompkins "understood" his rights is simply the absence of evidence that he did not understand them: "Thompkins received a written copy of the Miranda warnings; Detective Helgert determined that Thompkins could read and understand English; and Thompkins was given time to read the warnings. Thompkins, furthermore, read aloud the fifth warning ....,"102 Notwithstanding the Court's ruling that Thompkins' understanding (or lack thereof) serves as the lynchpin distinguishing his waiver from the type of waiver ruled out in Miranda and Butler, the Court does not seem overly concerned with the robustness of that understanding.

Again, the majority's approach in Thompkins-like its relative indifference to actual "understanding" in Powell-shows that the Court is not really concerned that a suspect achieve a full and genuine comprehension of her rights. "Understanding" in both cases simply means that the police provided the defendant with "fair notice."

Due process rules requiring "fair notice" often place, or imply, some level of responsibility on the audience to figure out the notice provided. Analogously, George Thomas notes that under due process principles, " $[t]$ he prisoner facing loss of good time credits and the parolee facing parole revocation can waive the right to a hearing by simply not appearing after notice has been given." ${ }^{103}$ In those contexts, due process is satisfied so long as "the prisoner and the parolee had notice and failed to exercise the right about which they were notified."104 Thus, due process "fair notice" rules generally do not inquire whether most or all of the intended audience actually received and comprehended the notice, but rather whether they had a reasonable opportunity to do so, if they took some initiative as responsible citizens to ascertain and understand the information being made available. Procedural due process is widely understood "at a minimum" to "require that deprivation of life, liberty or property by adjudication be preceded by notice and opportunity for hearing appropriate to the nature of the case." 105

101. Id.

102. Id.

103. Thomas, supra note 47 , at 1099.

104. Id. at 1100.

105. Mullane v. Cent. Hanover Bank \& Tr. Co., 339 U.S. 306, 313 (1950); see also Fuentes v. Shevin, 407 U.S. 67,80 (1972) (observing that procedural due process is "the right to notice and an opportunity to be heard ... 'at a meaningful time and in a meaningful manner"' (quoting Armstrong v. Manzo, 380 U.S. 545, 552 (1965))); Niki Kuckes, Civil Due Process, Criminal Due Process, 25 YAle L. \& POL'Y Rev. 1, 2 (2006) (noting the procedural due process requirement that "a person may not constitutionally be deprived of 'life, liberty or property' by 
The due process-like "fair notice" feature is evident in Powell and Thompkins: both operate with a conception of "understanding" concerned primarily with whether police have given the suspects notice and a reasonable opportunity to understand and exercise their rights. But the Court was not concerned with whether suspects-often of low intelligence and relatively uneducated-actually comprehend their rights or are affirmatively empowered to assert them.

\section{B. Maryland v. Shatzer: Miranda's Expiration Date and a New Prophylactic Antibadgering Rule}

The Roberts Court's other Fifth Amendment decision, Maryland $v$. Shatzer, placed an "expiration date" on a suspect's invocation of his right to counsel in a custodial interrogation. ${ }^{06}$ Shatzer was written against the backdrop of Miranda and Edwards v. Arizona. ${ }^{107}$ Under Miranda, a suspect in custodial interrogation can invoke either the Fifth Amendment right to silence or the Fifth Amendment right to counsel (or both). ${ }^{108}$ In either case, once the suspect has invoked the right to silence or counsel, "interrogation must cease." 109 If the suspect invokes the right to silence, police must cease the interrogation, but may reapproach after some period of time and again ask the defendant to waive his rights. ${ }^{110}$

The rule is different if the defendant invokes his right to counsel. In Edwards, the Court held that "when an accused has invoked his right to have counsel present during custodial interrogation, a valid waiver of that right cannot be established by showing only that he responded to further police-initiated custodial interrogation even if he has been advised of his rights." 111 When a defendant has invoked his right to counsel, he has communicated to police that "he is not capable of undergoing ... questioning without advice of counsel," and thus a later waiver is presumed to be the subject of the inherently compelling

governmental action without notice and a meaningful opportunity to be heard."); Martin H. Redish \& Lawrence C. Marshall, Adjudicatory Independence and the Values of Procedural Due Process, 95 YALE L.J. 455, 475 (1986) ("[T]he Supreme Court has often stated that the core rights of due process are notice and hearing ....").

106. 130 S. Ct. $1213,1227(2010)$.

107. 451 U.S. 477 (1981).

108. Miranda v. Arizona, 384 U.S. 436, 478-79 (1966).

109. Shatzer, 130 S. Ct. at 1219 (citing Miranda, 384 U.S. at 473-74).

110. See Michigan v. Mosley, 423 U.S. 96, 106-07 (1975) (holding that there was no Miranda violation when officers "gave full 'Miranda warnings' to [the person in custody] at the very outset of each interrogation, subjected him to only a brief period of initial questioning, and suspended questioning entirely for a significant period before beginning the interrogation that led to his incriminating statement").

111. Edwards, 451 U.S. at 484. 
pressures of custodial interrogation. ${ }^{112}$ As Justice Antonin Scalia explained in Shatzer, "[t]he Edwards presumption of involuntariness ensures that police will not take advantage of the mounting coercive pressures of 'prolonged police custody,' by repeatedly attempting to question a suspect who previously requested counsel until the suspect is "badgered into submission." 113 Invocations of the right to counsel during custodial interrogation bar future questioning about any offense, not just the offense that prompted the initial invocation. ${ }^{114}$

In Shatzer, all members of the Court agreed on the fundamental problem: without some endpoint, "every Edwards prohibition of custodial interrogation of a particular suspect would be eternal[,]" and would include interrogations pertaining to "a different crime" and those conducted "by a different law enforcement authority." 115 At oral argument in Shatzer, Justice Samuel Alito posed what he called "an extreme hypothetical":

Someone is taken into custody in Maryland in 1999 and questioned for joy riding, released from custody, and then in 2009 is taken into custody and questioned for murder in Montana.

Now, at the time of the first questioning, the ... suspect invokes the Fifth Amendment right to counsel. Now, does the Edwards rule apply to the second interrogation? ${ }^{1}$

Petitioner's counsel answered "Yes," "117 which prompted Professor Susan Bandes to note, "[i]f so, Edwards' days are numbered." 18

112. Arizona v. Roberson, 486 U.S. 675,681 (1988).

113. Shatzer, $130 \mathrm{~S}$. Ct. at 1220 (citations omitted) (quoting Roberson, 486 U.S. at 686 and id. at 690 (Kennedy, J., dissenting), respectively).

114. Roberson, 486 U.S. at $677-78$.

115. Shatzer, $130 \mathrm{~S}$. Ct. at 1222; see also id. at 1228 (Stevens, J., concurring in judgment) ("I agree that the presumption from Edwards . . is not "eternal."' (citations omitted) (quoting id. at 1222 (majority opinion))).

116. Transcript of Oral Argument at 31-32, Shatzer, 130 S. Ct. 1213 (No. 08-680) [hereinafter Shatzer Transcript], available at http://www.supremecourt.gov/oral_arguments/ argument_transcripts/08-680.pdf.

117. Id. at 32. Justice Alito later posed an even more extreme hypothetical:

Let me pose you my hypothetical again, the same joy riding questioning, and then 40 years later after the person has gotten a law degree and become an entrepreneur and made $\$ 20$ million, he's taken into custody and questioned by the Federal authorities for stock fraud. Forever, you know, this right that was invoked back in adolescence continues forever.

Id. at 34. Petitioner's counsel replied, "It should." Id.

118. Susan A. Bandes, Bright Line Fever: The Argument in Maryland v. Shatzer, ACS BLOG (Oct. 6, 2009), http://www.acslaw.org/node/14305. 
Given the agreement that Edwards invocation should not be "eternal," the Court's task in Shatzer was to craft a specific rule limiting the invocation in some way. The Court did so by adopting a rule that Edwards invocations of the right to counsel end fourteen days after the suspect's release from Miranda/Edwards police custody. Thus, a defendant like Shatzer who was released from the interrogation room back into the general prison population is no longer in "custody" for Miranda/Edwards purposes. ${ }^{11}$

Rather than create this fourteen-day rule, the Court could have held that the prohibition on talking to a suspect who invoked the right to counsel ended the instant the suspect was released from custody. The "end of custody" rule had been accepted by many lower courts ${ }^{120}$ and was noted as a possibility by Justice Thomas, who concurred in part. ${ }^{121}$ Instead, the Court created a new Fifth Amendment "prophylactic" rule: once a suspect invoked his right to counsel, police could attempt to reinterrogate him only after a fourteen-day break in Miranda custody. The Court settled on fourteen days because, according to Justice Scalia, "[i]t seems to us" to be the right length of time. ${ }^{122}$

This new rule is designed to prevent police from "coerc[ing] or badger[ing] [a suspect] into abandoning his earlier refusal to be questioned" without the presence of counsel. ${ }^{123}$ The fourteen-day period protects the suspect against police badgering by "provid[ing] plenty of time for the suspect to get reacclimated to his normal life, to consult with friends and counsel, and to shake off any residual coercive effects of his prior custody." 124

Thus, the Court in Shatzer did not choose the least suspect-friendly rule. It was willing to create a new "prophylactic" rule (albeit one with a fairly short fuse) to prevent a particular evil: police badgering of a suspect who has already invoked his rights. While the Roberts Court's interrogation decisions show little concern for protecting suspects from

119. Shatzer, 130 S. Ct. at 1223-24.

120. Id. at 1220 ("Lower courts have uniformly held that a break in custody ends the Edwards presumption ...." (citing People v. Storm, 52 P.3d 52, 61-62 n.6 (Cal. 2002))).

121. Id. at 1227-28 (Thomas, J., concurring in part). Notably, Justice Thomas did not actually express the view that the Edwards presumption should even last until the end of Miranda custody. Justice Thomas, showing his continued willingness to overrule precedent, stated, "It is not apparent to me that the presumption of involuntariness the Court recognized in Edwards is justifiable even in the custodial setting to which Edwards applies it." Id. at 1227 (citing Minnick v. Mississippi, 498 U.S. 146, 160 (1990) (Scalia, J., dissenting)). Justice Thomas thus explained that he would not extend $E d w a r d s$ beyond its facts: "But even if one believes that the Court is obliged to apply Edwards to any case involving continuing custody, the Court's opinion today goes well beyond that." Id.

122. Id. at $1223-24$ (majority opinion).

123. Id. at 1220 .

124. Id. at 1223. 
the inherent compulsion of custodial interrogation, the Court does seem to retain one concern: excessive badgering by police of a suspect who has already told them she does not want to talk, or needs a lawyer. ${ }^{125}$

The Shatzer Court's concern about preventing police from badgering a suspect who has already invoked his rights appears again in its Sixth Amendment Montejo v. Louisiana decision, discussed below. This suggests that part of the Court's vision for "fair play" in interrogations is respecting the voluntary choices of autonomous agents. The Court is chipping away at or eliminating rules designed to protect what the Warren Court viewed as the inherent vulnerabilities shared by most interrogation suspects. But in Shatzer the Court went so far as to create a new prophylactic rule to protect the assertion of rights by an autonomous suspect. This same concern will be seen reflected in Montejo below.

\section{RESHAPING RULES FOR SIXTH AMENDMENT INTERROGATION: "FAIR PLAY" FOR BOTH DEFENDANTS AND PROSECUTORS}

The Roberts Court issued two Sixth Amendment interrogation decisions, Kansas v. Ventris and Montejo v. Louisiana, both written by Justice Scalia. Montejo received more attention, as it overruled the twenty-three-year-old precedent of Michigan v. Jackson. ${ }^{126}$ In doing so, the Court cleared away a large portion of Sixth Amendment interrogation law, giving the Roberts Court the opportunity and doctrinal space to create new rules on a relatively clean slate. Ventris is also quite important, however, not only for its holding - that statements taken in violation of Massiah, outside the presence of counsel, can be used to impeach a testifying defendant-but for what its reasoning reveals about the long-opaque nature of the values underlying Sixth Amendment interrogation limits. Together, the two decisions, like the Roberts Court's Fifth Amendment interrogation cases, show a Court crafting rules to ensure "fair play" in interrogations, rather than to protect vulnerable defendants.

A. Kansas v. Ventris: "Fair Play," Impeaching a Defendant's Testimony, and Statements Obtained in Violation of the Sixth Amendment

Kansas v. Ventris was the first decision under Chief Justice Roberts' tenure relating to Sixth Amendment rights during police interrogation. In Ventris, Justice Scalia, writing for a seven-member majority, held that a defendant's incriminating statements, even if obtained in violation of the Sixth Amendment "strictures" imposed in Massiah v. United

125. Id. at $1220-21$.

126. Montejo v. Louisiana, 129 S. Ct. 2079, 2091 (2009). 
States, were admissible for the purpose of impeaching the defendant's later testimony at trial. ${ }^{127}$ Justice John Paul Stevens, joined by Justice Ginsburg, dissented. ${ }^{128}$

The Court's holding and reasoning together reveal several notable features about the Roberts Court's view of the underlying nature of the Sixth Amendment. First, Justice Stevens, in dissent, accused the Court of reducing Massiah to a "prophylactic" rule. ${ }^{129}$ On the contrary: Ventris actually affirms that Massiah is not a "prophylactic" rule designed to protect some other Sixth Amendment right, but rather is itself a part of the Sixth Amendment. Among other things, this means that police violate the Sixth Amendment - and are potentially liable in a $\S 1983^{130}$ civil action for deprivation of rights - by intentionally interrogating a represented, charged defendant about the charged offense. It also means, as Justice Scalia explained, that exclusion of statements for all potential trial purposes does not flow automatically from a violation of the Sixth Amendment right to counsel. ${ }^{131}$

Second, the opinion suggests Massiah is based on a conception of "fair play" in the criminal process. This is evident in the two key parts of Ventris: first, that interrogators violate the Sixth Amendment the moment they interrogate an uncounseled (but charged) defendant without a waiver because to do so unfairly exploits the unequal powers of the two parties; and second, that even when a statement is excluded from the government's case-in-chief, it would be unfair to allow the defendant to take the stand and testify inconsistently with that prior statement. ${ }^{132}$ In Ventris, then, "fair play" cuts both ways.

Explaining these points requires a brief description of the legal landscape leading up to Ventris. Before Ventris, the Court had consistently held that statements taken in violation of various Fifth and Sixth Amendment "prophylactic" protections could be used to impeach a testifying defendant. In Harris v. New York, ${ }^{133}$ the Court held that statements taken in violation of Miranda-specifically when "no warning of a right to appointed counsel was given before questions were put to petitioner when he was taken into custody"-were admissible to impeach the defendant's trial testimony, even though inadmissible in the prosecution's case-in-chief. ${ }^{134}$ The Court reasoned that it would not allow "[t]he shield provided by Miranda [to] be perverted into a license

127. Kansas v. Ventris, 129 S. Ct. 1841, $1844-45,1847$ (2009).

128. Id. at 1847 .

129. Id. at 1848 (Stevens and Ginsburg, JJ., dissenting).

130. 42 U.S.C. $\$ 1983(2006)$.

131. Ventris, $129 \mathrm{~S}$. Ct. at 1847.

132. Id. at 1846 .

133. 401 U.S. 222 (1971).

134. Id. at 224 . 
to use perjury by way of a defense." ${ }^{135}$ Moreover, the Court reasoned that if the purpose of the exclusionary rule was to have "a deterrent effect on proscribed police conduct, sufficient deterrence flows when the evidence in question is made unavailable to the prosecution in its case in chief." 136 Any further deterrence to be gained by also excluding confessions from use in impeachment, the Court reasoned, was "speculative.",137

Later, in Oregon $v$. Hass, ${ }^{138}$ the Court applied the same rule, permitting the prosecution to impeach the defendant with statements he gave after invoking his Fifth Amendment right to counsel-a different Miranda violation than the failure to give warnings in Harris. ${ }^{139}$ In Hass, the Court acknowledged the risk created by this rule: "One might concede that when proper Miranda warnings have been given, and the officer then continues his interrogation after the suspect asks for an attorney, the officer may be said to have little to lose and perhaps something to gain by way of possibly uncovering impeachment material." 140 The Court dismissed this as a "speculative possibility" that did not change its conclusion. ${ }^{141}$

The Court reached the same result in the Sixth Amendment context in Michigan $v$. Harvey, ${ }^{142}$ allowing the prosecution to impeach a testifying defendant with statements obtained in violation of Michigan $v$. Jackson's rule that "after a defendant requests assistance of counsel, any waiver of Sixth Amendment rights given in a discussion initiated by police is presumed invalid." ${ }^{143}$ Citing Harris and Hass, ${ }^{144}$ the Court explained that voluntary statements may be used in impeachment even when they are inadmissible in the government's case-in-chief "when the violations alleged by a defendant relate only to procedural safeguards that are 'not themselves rights protected by the Constitution,' (Miranda rules), but are instead measures designed to ensure that constitutional rights are protected."

In Ventris, the Sixth Amendment violation was not a violation of Michigan v. Jackson's "prophylactic" rule, as in Harvey. Instead, the statements used to impeach Ventris, the testifying defendant, were

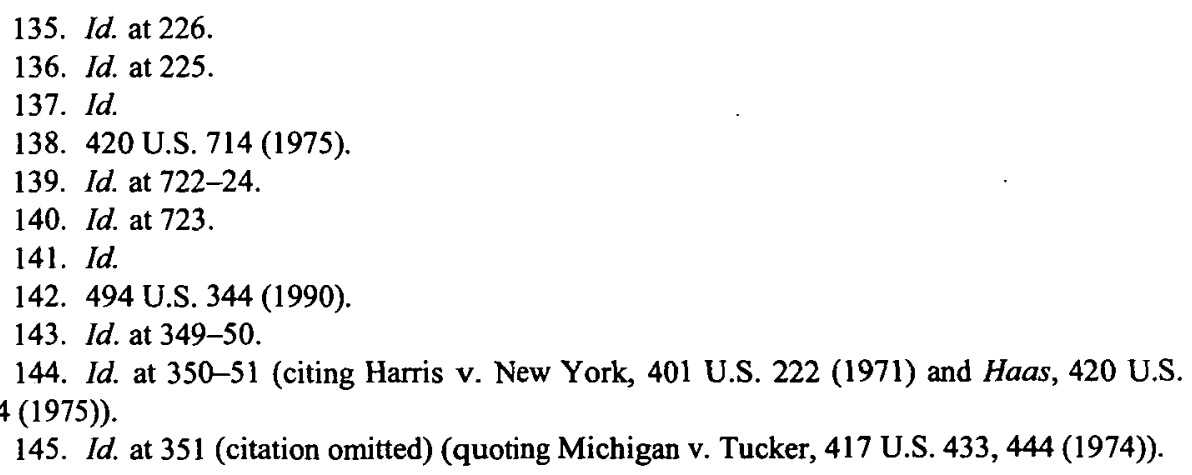


obtained by a jailhouse informant planted by police in Ventris' pretrial holding cell. Ventris was charged with felony murder and aggravated theft, among other counts, in the robbery and shooting death of Ernest Hicks. At trial, Ventris took the stand in his own defense and blamed the robbery and shooting on his codefendant Rhonda Theel, who pleaded guilty and testified against Ventris at trial. ${ }^{146}$ The State impeached Ventris with testimony from the jailhouse informant, who testified that Ventris had confessed to him that "[h]e'd shot this man in his head and in his chest and taken his keys, his wallet, about $\$ 350.00$, and ... a vehicle." ${ }^{\prime 147}$ Notably, the jury apparently did not fully credit this informant's testimony, as it acquitted Ventris of felony murder. The jury did, however, convict Ventris on aggravated burglary and aggravated robbery charges. ${ }^{148}$

The Supreme Court assumed, without deciding, that the jailhouse informant had deliberately elicited this confession from Ventris, thereby violating the rule in Massiah against deliberately eliciting statements from a represented, charged defendant without a valid waiver of the Sixth Amendment right to counsel. ${ }^{149}$ Determining "[w]hether otherwise excluded evidence can be admitted for purposes of impeachment[,]" Justice Scalia explained, "depends upon the nature of the constitutional guarantee that is violated." "I50 In light of Harris, Hass, and Harvey, the obvious route to permitting impeachment use would be to declare Massiah a "prophylactic" rule-like Miranda and Michigan v. Jackson-and apply the Harris-Hass-Harvey rule that "statements taken in violation of only the prophylactic Miranda [or Jackson] rules... are admissible to impeach conflicting testimony by the defendant." 151 Professor Carol S. Steiker has observed that these prior decisions had left:

open the door to concluding that Massiah's ban on questioning in the absence of counsel after the commencement of adversary proceedings, like Miranda's ban on the questioning of suspects in custody in the absence of warnings, is not an interpretation of the Constitution, but rather a prophylactic rule designed to sweep more broadly than the actual constitutional right in order to deter police misconduct. ${ }^{152}$

146. Kansas v. Ventris, 129 S. Ct. 1841, 1844 (2009).

147. Id. (quoting Joint Appendix at 154, 150, Ventris, 129 S. Ct. 1841 (No. 07-1356), 2008 WL 4905476 at ${ }^{*} 154,{ }^{*} 150$ ) (internal quotation marks omitted).

148. Id.

149. Id. at 1845 (citing Massiah v. United States, 377 U.S. 201, 206 (1964)).

150. Id.

151. Michigan v. Harvey, 494 U.S. 344, 350 (1990).

152. Carol S. Steiker, Counter-Revolution in Constitutional Criminal Procedure? Two 
If so, Steiker predicted, "the consequences for the Massiah rule likely would be very similar to the consequences that have obtained already in the Miranda context." 153 Among other things, "statements taken in violation of Massiah likely would be permitted as impeachment against a defendant who testified contrary to such statements at trial."154 Recasting Massiah as a "prophylactic" rule, Steiker argues, would constitute a "re-working of Massiah" similar to the Court's past constriction of Fourth and Fifth Amendment rules. ${ }^{155}$

Does Ventris accomplish, in the Sixth Amendment context, the "counter-revolution in constitutional criminal procedure" that Steiker had observed in the Fourth and Fifth Amendments but not yet in the Sixth Amendment? Justice Stevens seems to think so. Dissenting in Ventris, Justice Stevens claimed that the majority's holding "relies on the view that a defendant's pretrial right to counsel is merely 'prophylactic' in nature," and that "any violation of this prophylactic right occurs solely at the time the State subjects a counseled defendant to an uncounseled interrogation, not when the fruits of the encounter are used against the defendant at trial." reducing the pretrial right to counsel to a "prophylactic" right, arguing that "[p]lacing the prophylactic label on a core Sixth Amendment right mischaracterizes the sweep of the constitutional guarantee."157

\section{Massiah Is Not a Prophylactic Rule, and Massiah Violations Occur at the Time of Uncounseled Interrogation}

Before Ventris, commentators had long made two assertions about Massiah: (1) it is part of the Sixth Amendment itself, not a "prophylactic" rule; ${ }^{158}$ and (2) like the Fifth Amendment privilege against self-incrimination, Massiah is violated when the statement is introduced at trial, not at the time of interrogation. ${ }^{159}$ The Court in

Audiences, Two Answers, 94 MICH. L. REV. 2466, 2527 (1996).

153. Id.

154. Id.

155. Id.

156. Kansas v. Ventris, 129 S. Ct. 1841,1848 (2009) (Stevens, J., dissenting).

157. Id.

158. See Grano, Prophylactic Rules in Criminal Procedure, supra note 17, at 12223 (asserting that it is "erroneous" to describe the Massiah rule "as prophylactic"); Stephen J. Schulhofer, Confessions and the Court, 79 MiCH. L. REV. 865, 889 (1981) ("[T]he Massiah 'exclusionary rule' is not merely a prophylactic device[.]"); James J. Tomkovicz, Saving Massiah from Elstad: The Admissibility of Successive Confessions Following a Deprivation of Counsel, 15 WM. \& MARY BILL RTS. J. 711, 754-55 (2007) ("[I]t is difficult to imagine how the Massiah doctrine might be recast as mere prophylactic guidelines that guard against presumed, but not actual, right to counsel violations."). But see Steiker, supra note 152, at 2527 (claiming the Court has left the question "open").

159. See Schulhofer, supra note 158 , at 889 ("Massiah . . . is not intended to deter any pretrial behavior whatsoever. Rather, Massiah explicitly permits government efforts to obtain 
Ventris confirmed the first point and rejected the second. ${ }^{160}$

As noted above, one easy route for the Court to permit impeachment use of Massiah violations would be to declare Massiah a "prophylactic rule"-something prior decisions had left "open."161 The Court's line of cases in Harris v. New York, ${ }^{162}$ Oregon v. Hass, ${ }^{163}$ and Michigan $v$. Harvey $^{164}$-all permitting impeachment use by declaring the violated right merely "prophylactic"-paved the way for that approach. But contrary to Justice Stevens' claim, the Ventris majority did not follow that route.

Justice Scalia, writing for the majority, first explained that "[w] hether otherwise excluded evidence can be admitted for purposes of impeachment depends upon the nature of the constitutional guarantee that is violated. Sometimes that explicitly mandates exclusion from trial, and sometimes it does not." 165 To illustrate, he first mentioned the Fifth Amendment right against self-incrimination. Given the nature of that right - protection from being "compelled to give [testimony] against" oneself - the right "is violated whenever a truly coerced confession is introduced at trial[.]"166

Justice Scalia contrasted this with Fourth Amendment violations and violations of "Fifth and Sixth Amendment prophylactic rules forbidding certain pretrial . . . conduct." ${ }^{, 167}$ The Fourth Amendment, for example, is not a trial right against the use of certain evidence, but rather is a right against unreasonable searches and seizures. Thus, the exclusion of evidence obtained from a Fourth Amendment violation is not automatic, but rather is a remedy imposed by the Court based on a cost-benefit analysis. Justice Scalia asserted that "[t]he same is true" for violations of Fifth and Sixth Amendment "prophylactic" rules. ${ }^{168}$

How does a Massiah violation fit into this scheme? Rather than call

information from an indicted suspect, so long as that information is not used 'as evidence against him at his trial.' . . . [I]t is the admission at trial that in itself denies the constitutional right."); James J. Tomkovicz, The Massiah Right to Exclusion: Constitutional Premises and Doctrinal Implications, 67 N.C. L. REV. 751, 763 (1989) ("[A] sixth amendment violation occur[s] at the time of, and only at the time of, admission at trial of the fruits of an uncounseled pretrial encounter.").

160. Ventris, $129 \mathrm{~S}$. Ct. at $1845-47$.

161. Steiker, supra note 152 , at 2527.

162. 401 U.S. 222, 223-26 (1971) (statements in absence of Miranda warnings could be used to impeach).

163. 420 U.S. 714, 723-24 (1975) (statements after suspect invoked Miranda rights could be used to impeach).

164. 494 U.S. 344, 345-46 (1990) (statements in violation of Michigan v. Jackson could be used to impeach).

165. Ventris, 129 S. Ct. at 1845.

166. Id.

167. Id.

168. Id. 
Massiah a "prophylactic" rule, Justice Scalia explained the nature of a Massiah violation: specifically, when police violate a defendant's right to counsel during a pretrial interrogation, the violation occurs at the time of the interrogation, not upon the later admission of that evidence at trial. ${ }^{169}$ Because the violation is complete at the time of the interrogation, the question of admissibility at trial-as in the Fourth Amendment context- - does not involve, therefore, the prevention of a constitutional violation, but rather the scope of the remedy for a violation that has already occurred." ${ }^{170}$ Whether to permit impeachment use of a statement obtained in violation of Massiah thus depends-like a Fourth Amendment violation-on whether the relative costs (to the truth-seeking process) and benefits (deterring the earlier violation) mandate exclusion. On that point, the Court's "precedents make clear that the game of excluding tainted evidence for impeachment purposes is not worth the candle." $17 \mathrm{~F}$

Thus, implicit in the Court's reasoning is the conclusion that Massiah violations are actual Sixth Amendment violations, not merely violations of a "prophylactic" rule. The majority also says so fairly explicitly: "We hold that the informant's testimony, concededly elicited in violation of the Sixth Amendment, was admissible to challenge Ventris's inconsistent testimony at trial."172

\section{2. "Fair Play" in Interrogation and Prosecution}

Beyond clarifying the nature of the Sixth Amendment right to counsel, Ventris suggests that the right is based on underlying values of "fair play" in criminal prosecution. Uncounseled pretrial interrogation (after charging) is prohibited because it violates "fair play"-_"the basic dictates of fairness in the conduct of criminal causes." play" is also the reason prosecutors are permitted to impeach defendants with prior inconsistent statements, even when obtained illegally: it would be unfair to allow a defendant to testify at his trial inconsistently with prior statements, immune from impeachment.

In Massiah itself, and in later decisions, the Supreme Court never provided a fully convincing explanation for why police are prohibited from eliciting statements from a represented defendant without counsel (or waiver of the right to counsel). ${ }^{174}$ It is clear that Massiah's

169. Id. at 1846.

170. Id.

171. Id.

172. Id. at 1847 (emphasis added).

173. Id. at 1846 (quoting Massiah v. United States, 377 U.S. 201, 205 (1964)) (internal quotation marks omitted).

174. Tomkovicz, supra note 159 , at 762 ("The rationale for sixth amendment suppression is not at all clear. The Court has failed to rationalize Massiah-based exclusion with clarity or 
protections are not based primarily on the concerns originally motivating the Miranda decision: protecting defendants from the inherent compulsion of the interrogation room. Massiah is not triggered by "custodial interrogation," as Miranda is. Moreover, Massiah prohibits the police from deliberately eliciting statements even when the defendant does not know he is speaking to a government agent and thus presumably can feel no compulsion from the state to speak.

Commentators have long debated what core theory, if any, best explains Massiah. Professor H. Richard Uviller has posited three different conceptions of the lawyer's role that might underlie the decision: (1) "preparatory assistance," (2) "preventive assistance," and (3) "adversarial assistance." "Ventris, I argue, shows the Court endorsing the "preventive assistance" model (or what I would call "fair play").

Uviller explains that the fundamental idea of the first model, "preparatory assistance," is to "prevent[] . . . the ultimate injustice[,]" namely "the erroneous conviction of an innocent person[,]" by providing "help for an accused person in need." "177 Because the purpose of this help is to prevent conviction of the innocent, the courts should require "counsel's special talent and concern" at any "vital juncture" when counsel's presence is required to "enhance the reliability of the verdict"- for example, "counsel might assist in preserving evanescent exculpatory evidence or by employing the mechanisms of adjudication to obtain a valid outcome." "178 Thus, the "preparatory assistance" model might be referred to as a "just outcome" model.

Uviller's second model is that of counsel providing "preventive assistance" or ensuring "fair play." This model assumes a criminal defendant faces an "uneven match" at the hands of the "immense forces of the state arrayed against him." 179 As Uviller explains:

[Z]ealous counsel is the best instrument to ameliorate the

consistency, proffering deficient and potentially contradictory explanations." (footnote omitted)); H. Richard Uviller, Evidence from the Mind of the Criminal Suspect: $A$ Reconsideration of the Current Rules of Access and Restraint, 87 Colum. L. REv. 1137, 1164 (1987) ("We are not much aided in discovering the answers by the Court's own explanation in the principal cases. The majority simply informs us that the reason Massiah's and Williams' statements are unusable is because, though accused, the defendants were denied the assistance of counsel and did not operatively waive their entitlement. While it is undeniable that a lawyer might have 'assisted' them in the sense of reducing the culpable evidence available to the prosecution, the Court does not justify this construction of 'assistance' nor explain why the right to such assistance should depend entirely on the formalistic moment of 'accusation."').

175. Massiah, 377 U.S. at 206-07.

176. Uviller, supra note 174 , at 1169-83.

177. Id. at 1169 .

178. $I d$.

179. Id. at 1173 . 
inherent disadvantage of the defendant's position and give him a fair, fighting chance. . . . The theory of "preventive assistance" is wholly different from the "preparatory assistance" argument in that while the latter is designed to promote a just result; this one is dedicated to the idea of a fair fight. ${ }^{180}$

Other commentators have articulated theories similar to Uviller's "preventive assistance" model. Professors Silas Wasserstrom and William J. Mertens claim that "Massiah . . . seems directly concerned with the balance of litigative advantages between the prosecution and the defense at trial[]" by "assur[ing] that prosecutors will not secure any trial advantages from the defendant by going outside established, and judicially regulated, channels and that the defense counsel will participate in equal terms with the prosecutor.",

Professor James Tomkovicz's theory of the Sixth Amendment is also similar to Uviller's "preventive assistance" or "fair play" model. Tomkovicz states, "The grant of counsel to the inherently inferior defendant is designed to promote balanced contests by equalizing the adversaries," given that the prosecution in our system's "contest between opposing sides ... is significantly more powerful in most, if not all, relevant respects." $" 182$ Counsel is thus guaranteed to promote "“[r]ough equality' between the opponents," to ensure "not only . . . accurate and truthful results, but also ... that those results are the products of adversarial fair play." 183 In a later article, Tomkovicz explains that "the Sixth Amendment's sole original objective . . is . . . to equalize an accused and protect against the increased risks of conviction that result when a defendant must deal with the legal system or an expert adversary without a lawyer's guidance." ${ }^{184}$ All of these commentators are discussing a similar notion: equalizing the process (making it fair) by inserting counsel for the defendant.

Uviller's third model, "adversarial assistance," is based on the premise that in an adversarial system, "ex parte access is anathema."185 In an adversarial system, as opposed to an inquisitorial one, "the state may not cross into the accused's territory to sample the contents of the defendant's mind without the concurrence of the guardian of the fortress, his legal adviser." $" 186$ Tomkovicz also sometimes articulates

180. Id.

181. Silas Wasserstrom \& William J. Mertens, The Exclusionary Rule on the Scaffold: But Was it a Fair Trial?, 22 AM. CRIM. L. REv. 85, 175-76 (1984).

182. Tomkovicz, supra note 159 , at 753 .

183. Id. (footnote omitted).

184. Tomkovicz, supra note 158 , at 753 .

185. Uviller, supra note 174 , at 1176

186. Id. Uviller ultimately concludes that none of his three possible theories adequately 
similar purposes. He notes that Massiah protects "[c]ounsel's advice not to cooperate with the state by divulging inculpatory information" to the prosecution, a rule which "guarantees that the government will shoulder the entire burden of proving guilt without assistance from its adversary." 187 Tomkovicz explains elsewhere that "[i]n the pretrial setting defined by Massiah's doctrine, legal assistance helps prevent an accused from providing the adversary with ammunition that can seal his fate." "188 These statements resonate with Uviller's "adversarial assistance" model, which is concerned with preserving the adversarial system. For Tomkovicz, however, the core justification for preserving the "adversarial system" seems to be ensuring "fair play"; he notes that Massiah assures that "the accused will not be convicted on the basis of advantages the government has secured by denying adversarial equalization." 189 Thus for Tomkovicz, the "adversarial" values are fundamentally about "equalization" of the contest between the partiesthat is, about fairness.

Ultimately, it seems that the "adversarial assistance" model must collapse into one of the other two models (as it appears to do for Tomkovicz). Recognizing that ours is an adversarial system of justice does little to provide an ultimate explanation for whether and when counsel must be provided. An adversarial system is not an end in itself-it is valuable (if at all) because it serves some other goal. Thus, it might be argued that an adversarial system is the best process for discerning truth - that is, a just outcome. ${ }^{190}$ Alternately, it might be argued that we value an adversarial system because that process is most fair, in the sense of providing an equal contest ("fair play") between the two interested parties-the government and the accused. ${ }^{191}$ Or one

justify the Massiah rule, which he states is most likely based on (inappropriate) "judicial discomfort with the anomalous inquisitorial component in the adversary design." Id. at 1183. For present purposes, however, these three models provide a useful way to analyze the Court's definition of the Sixth Amendment right in Ventris.

187. Tomkovicz, supra note 159 , at 766-67.

188. Tomkovicz, supra note 158 , at 754 .

189. Id. (emphasis added).

190. See Gardner v. Florida, 430 U.S. 349, 360 (1977) (referring to the Court's "belief that debate between adversaries is often essential to the truth-seeking function of trials"); Strickland v. Washington, 466 U.S. 668, 685 (1984) (noting that effective representation by counsel "is critical to the ability of the adversarial system to produce just results").

191. See, e.g., McNeil v. Wisconsin, 501 U.S. 171, 188-89 (1991) (Stevens, J., joined by Marshall and Blackmun, JJ., dissenting) ("Undergirding our entire line of cases requiring the police to follow fair procedures when they interrogate presumptively innocent citizens suspected of criminal wrongdoing is the longstanding recognition that an adversarial system of justice can function effectively only when the adversaries communicate with one another through counsel and when laypersons are protected from overreaching by more experienced and skilled professionals. Whenever the Court ignores the importance of fair procedure in this context and describes the societal interest in obtaining 'uncoerced confessions' from pretrial 
might argue that an adversarial model serves both the values of truth and fairness. ${ }^{192}$ In any event, the "adversarial system" model seems to have little value independent of the underlying value or values that system is presumed to promote. Indeed, as noted below, the Court in Ventris disregards the "adversarial assistance" model as an independent reason for providing counsel during interrogations.

Thus, the three justifications commentators have articulated as possibly underlying Sixth Amendment interrogation rules are (1) "just outcome" (or "preparatory assistance"), (2) "fair play" (or "preventive assistance"), and (3) "adversarial system" (or "adversarial assistance"). As I will explain, the Ventris opinion rejected the "just outcome" model, disregarded the "adversarial system" model, and offered at least tentative endorsement of the "fair play" model.

In Ventris, Justice Scalia made several comments on the nature of the Sixth Amendment right to counsel in general and the Massiah right in particular. First, he stated that "[t]he core of the [Sixth Amendment] right to counsel is indeed a trial right, ensuring that the prosecution's case is subjected to "the crucible of meaningful adversarial testing." 193 As for the Massiah rule, the Court has "held that the right covers pretrial interrogations to ensure that police manipulation does not render counsel entirely impotent-depriving the defendant of 'effective representation by counsel at the only stage when legal aid and advice would help him.'

Justice Scalia's concern here for "police manipulation" could be understood in at least two ways. Perhaps he means police pressure of the sort that might lead an innocent person to make inculpatory statements. If that is what "police manipulation" means, Justice Scalia's concern looks like the "preparatory assistance"/"just outcome" model, in which counsel's core function is to prevent conviction of the innocent. On the other hand, "police manipulation" might also simply mean police obtaining an unfair advantage by getting an unwary defendant to implicate himself when a more savvy, empowered defendant would know to keep silent and not provide the advantage to his opponent. This understanding would suggest a "preventive assistance"/"fair play" model, meaning the preservation of a fair playing field-preventing police from winning the "game" before it really even starts. Justice Scalia did not clearly explain which of these concerns (or

detainees as an 'unmitigated good,' the Court is revealing a preference for an inquisitorial system of justice." (emphasis added)).

192. See Polk Cnty. v. Dodson, 454 U.S. 312, 318 (1981) ("The system assumes that adversarial testing will ultimately advance the public interest in truth and fairness.").

193. Kansas v. Ventris, 129 S. Ct. 1841, 1845 (2009) (quoting United States v. Cronic, 466 U.S. $648,656(1984))$.

194. Id. (quoting Massiah v. United States, 377 U.S. 201, 204 (1964)). 
perhaps both) he was describing.

Justice Scalia then considered the nature of the constitutional violation in a Massiah case. According to Justice Scalia, Massiah suggested (on the one hand) that "the violation occurred at the moment of the postindictment interrogation because such questioning "contravenes the basic dictates of fairness in the conduct of criminal causes" 195 - a "fair play" model. On the other hand, Massiah also suggested the violation only occurs when the statement is improperly "used against the defendant at ... trial"-a "just outcome" model. ${ }^{196}$ Faced with these two competing visions of the right, the Ventris Court chose the former and rejected the latter: "Now that we are confronted with the question, we conclude that the Massiah right is a right to be free of uncounseled interrogation, and is infringed at the time of the interrogation."197

Having decided that "the violation occur[s] at the moment of the postindictment interrogation," the Court appeared to be endorsing the theory that Massiah is premised on the "basic dictates of fairness in the conduct of criminal causes"198 - a "fair play" rationale for Massiah and the pretrial Sixth Amendment right to counsel. Unfortunately, the Court did not explain its choice very well. Instead of telling the reader why the Court chose the former option, Justice Scalia explained why the Court rejected the latter. Justice Scalia stated that it is "illogical" to say the violation occurs when the evidence is admitted because the right to counsel is "not denied... merely because the prosecution has been permitted to introduce evidence of guilt - even evidence so overwhelming that the attorney's job of gaining an acquittal is rendered impossible." 199 Thus, even in a case in which (putting any Massiah violation aside) the evidence of guilt is overwhelming, the defendant still has the right to the assistance of counsel. Counsel must be present and able to fight on the defendant's behalf, even when that fight is obviously doomed from the start. The right might be analogized to the right to have a coach for your baseball team, even when your Little League team is facing the Yankees: you still have a right to a coach, even though you will obviously lose against the overpowering and overmatched force against you. $^{200}$

Justice Scalia went on to explain that past cases have implicitly recognized that "the assistance of counsel has been denied" at the point

195. Id. at 1846 (quoting Massiah, 377 U.S. at 205).

196. Id. (quoting Massiah, 377 U.S. at 206-07) (internal quotation marks omitted).

197. Id.

198. Id. (quoting Massiah, 377 U.S. at 205) (internal quotation marks omitted).

199. Id. at 1846 .

200. As Uviller has noted, "it is surprisingly difficult to escape the sporting analogy" in Sixth Amendment right to counsel discussions. Uviller, supra note 174, at 1174. 
police interrogate a charged suspect without adequate warnings and waivers. ${ }^{201}$ In Patterson v. Illinois, ${ }^{202}$ the Court held "that the stringency of the warnings necessary for a waiver of the assistance of counsel varies according to 'the usefulness of counsel to the accused at the particular [pretrial] proceeding.",203 That is to say, counsel is required under the Sixth Amendment at interrogations because of "the usefulness of counsel" at that particular stage. Invoking the "usefulness of counsel" at interrogations again seems to reflect a "fair play" model of Sixth Amendment rights. A lawyer is "useful" at an interrogation by protecting the defendant from a potentially overwhelming adversary and keeping a defendant from "giving away the farm" at this early stage (and without the reciprocal benefit of a good plea deal). A lawyer is "useful" in keeping the playing field fairer.

Insofar as Justice Scalia's opinion chose the "fair play" theory of Massiah over the "just outcome" theory, the Court's description of the remedy shows that the Court's vision of "fair play" is markedly different from that articulated by commentators. Tomkovicz argues that if Massiah is rooted in a theory of "fair play," then "Massiah exclusion is akin to the suppression of statements under the Due Process and SelfIncrimination Clauses. Like those two guarantees, the Sixth Amendment safeguards an interest in not being convicted as a result of government methods deemed unfair by our Constitution."204 Accordingly, a statement taken in violation of Massiah should not be usable by the prosecution for any purpose, including impeachment. ${ }^{205}$

But the Court in Ventris decided that exclusion is not always required as a remedy for a Massiah violation. The reason prosecutors can impeach a testifying defendant with inconsistent pretrial statements, even ones unfairly obtained by the police in violation of the Sixth Amendment, is that it would be unfair to allow the defendant to "provide himself with a shield against contradiction of his untruths."

Professor Donald Dripps has called this the "waiver theory" of the Court's past impeachment cases. ${ }^{207}$ Dripps suggests that by "taking the stand and testifying contrary to the prior statement, [the defendant has] waived his privilege against the use of the previously compelled admission. ... Thus the defendant who testifies accepts the obligation

201. Ventris, 129 S. Ct. at 1846.

202. 487 U.S. 285 (1988).

203. Ventris, 129 S. Ct. at 1846 (quoting Patterson v. Illinois, 487 U.S. 285, 298 (1988)).

204. Tomkovicz, supra note 158 , at 755.

205. Id.

206. Ventris, 129 S. Ct. at 1846 (quoting Walder v. United States, 347 U.S. 62,65 (1954)) (internal quotation marks omitted).

207. Donald Dripps, Is the Miranda Caselaw Really Inconsistent? A Proposed Fifth Amendment Synthesis, 17 CONST. COMMENT. 19, 29-30 (2000). 
to answer truthfully the prosecutor's questions on cross."208 The defendant has "the alternative of not testifying, reinforced by an instruction to the jury to draw no inference of guilt from standing silent." ${ }^{209}$ When a defendant has given a previous statement to the police under unconstitutional circumstances or pressures, the government cannot build its case on that statement-that would not be fair. But it would also be unfair, the theory goes, for the defendant to affirmatively choose to take the stand and testify inconsistently with that prior statement.

Dripps argues that " $[t]$ he best interpretation recognizes that coercive questioning with the object of ultimate incrimination violates the privilege, and that use of the evidence constitutes a separate and distinct violation." 210 When the defendant chooses to take the stand and testify, fairness dictates that the defendant has waived his objection to the second violation - at least has waived the right to object if he testified inconsistently with that prior statement. ${ }^{211}$ In that case, "[t]he pretrial violation needs to be deterred, but the scope of the deterrent remedy is fairly subject to policy-based qualifications just as is the Fourth Amendment exclusionary rule. The constitutional concern is what happened in the interrogation room, not what happened at the trial.,"212

Dripps offered his theory as an explanation of New York v. Harris, but it also seems to fit the Court's approach in Ventris. The Ventris Court relied squarely on Walder, Harris, and Hass, each of which can be read as articulating a "fairness" concern: that permitting a defendant to testify free from cross-examination with a prior inconsistent statement is not "fair play." The Ventris Court quoted Walder in stating, "It is one thing to say that the Government cannot make an affirmative use of evidence unlawfully obtained. It is quite another to say that the defendant can ... provide himself with a shield against contradiction of his untruths.'

This is not an argument about the deterrence of constitutional violations; it is an argument about fairness. Even though the government cannot build its case on evidence illegally obtained, it would be unfair to allow a defendant to mislead the jury in the face of probative, reliable (but illegally obtained) evidence to the contrary. In Harris, the Court similarly stated:

208. Id. at 30.

209. Id.

210. Id. at $31-32$.

211. Id. at 32 .

212. Id; see also Commonwealth v. Edwards, 830 N.E.2d 158, 167 (Mass. 2005) ("[T] equitable principle, at the heart of the forfeiture by wrongdoing doctrine, [is] that a party may not gain advantage from his own wrong.").

213. Kansas v. Ventris, 129 S. Ct. 1841, 1846 (2009) (quoting Walder v. United States, 347 U.S. 62, 65 (1954)) (internal quotation marks omitted). 
Every criminal defendant is privileged to testify in his own defense, or to refuse to do so. But that privilege cannot be construed to include the right to commit perjury. . . . Having voluntarily taken the stand, petitioner was under an obligation to speak truthfully and accurately. ... The shield provided by Miranda cannot be perverted into a license to use perjury by way of a defense, free from the risk of confrontation with prior inconsistent utterances. ${ }^{214}$

This reasoning is not about the "prophylactic" nature of the Fifth Amendment right in Harris, but it instead concerns the fairness of permitting a defendant to testify inconsistently with a prior statement.

In Ventris, then, the Court permitted impeachment use of statements obtained in violation of Massiah not because Massiah is a "prophylactic" rule, but instead because the Court reasoned that it would be unfair to permit a defendant to affirmatively testify inconsistently with a prior statement while shielded by the Massiah rule - itself grounded on concerns for "fair play." The Court in Ventris used the terminology of both fairness and deterrence. The argument that the defendant should not be allowed to "provide himself with a shield against contradiction of his untruths" ${ }^{215}$ is a fairness argument. The unfairness of the defendant's inconsistency waives, or outweighs, his objection to the use of illegally obtained evidence. The remaining question is whether the evidence should nevertheless be excluded to deter the earlier constitutional violation, and on that score Justice Scalia confidently asserted that "the game of excluding tainted evidence for impeachment purposes is not worth the candle."

In this way, both aspects of the Ventris ruling-that the Sixth Amendment is violated at the time of the uncounseled pretrial interrogation, but that a resulting statement can be used to impeach a testifying defendant - can be explained by notions of "fair play." It is not fair to allow the government to try to secretly interrogate a represented defendant after charges have been filed, just as it is not fair for the defendant to be able to take the stand and contradict his past statements, even when those statements cannot be used against him in the government's case-in-chief.

B. Montejo v. Louisiana: After Erasing Michigan v. Jackson, a Blank Slate Remains

The Court's third interrogation decision in the October 2008 term, Montejo v. Louisiana, was also its most significant. In Montejo, the

214. Harris v. New York, 401 U.S. 222, 225-26 (1971) (citations omitted).

215. Ventris, $129 \mathrm{~S}$. Ct. at 1846 (quoting Walder, 347 U.S. at 65) (internal quotation marks omitted).

216. Id. 
Court overruled Michigan v. Jackson, a 1986 decision which held that once a defendant invoked the Sixth Amendment right to counsel at an arraignment or similar proceeding, the police were prohibited from initiating any interrogation of that defendant. ${ }^{217}$ The most notable consequence of this decision is how wide open Sixth Amendment interrogation doctrine has become now that Jackson has been overruled. Clearly, Montejo allows police to approach a charged, represented defendant outside the presence of counsel and seek a waiver. ${ }^{218}$ But the ruling may actually go much further-it clears the ground for the Court to hold in the future that police may return again and again to try and interrogate that defendant, even if he invokes his right to counsel at every turn. It is far from clear that the Court will go so far, but nothing in Montejo precludes that route. In one decision, the Roberts Court has opened up Sixth Amendment interrogation law wider than it has been in over twenty-five years.

While Montejo swept away most of Sixth Amendment interrogation law, the opinion consistently invokes a concern also articulated by the Court in Shatzer: the problem of police badgering suspects into waiving previously asserted rights. The Court's concern (and in particular, Justice Kennedy's concern) with police badgering -reflected both in Montejo and Shatzer-suggests that the Court may well create some sort of Edwards-like rule in the Sixth Amendment context, one that would prevent police from continually re-approaching represented suspects to seek waivers.

The case began when police arrested Jesse Montejo on September 6, 2002 , in connection with a robbery and murder. Montejo waived his Miranda rights and eventually confessed to shooting the victim in the course of a burglary. On September 10, Montejo was brought before a Louisiana state judge for a preliminary hearing, where he was charged with murder, denied bond, and appointed a lawyer. ${ }^{219}$

Later that day, police approached Montejo (before he had met with his lawyer) and asked him to go with them to help find the murder weapon. During the trip, he wrote a letter apologizing to the victim's widow. At trial, the letter (along with his earlier confession) was admitted over defense objection. Montejo was convicted and sentenced to death. ${ }^{220}$

On appeal, Montejo argued that police violated his Sixth Amendment right to counsel-as articulated in Massiah and Michigan

217. Montejo v. Louisiana, 129 S. Ct. 2079, 2091 (2009); Michigan v. Jackson, 475 U.S. $625,636(1986)$.

218. Montejo, 129 S. Ct. at $2090-91$.

219. Id. at 2082.

220. Id. 
v. Jackson ${ }^{221}$ - by approaching him after he had been appointed counsel. ${ }^{222}$ As noted above, a defendant facing police interrogation has at least two potential sources of protection: Fifth Amendment protections under Miranda and Sixth Amendment protections under Massiah.

In the Fifth Amendment context, the Court held in Edwards $v$. Arizona that if a suspect invokes his right to counsel, interrogation must cease and police are prohibited from re-initiating a later interrogation. ${ }^{223}$ In the Sixth Amendment context, the Court in Michigan v. Jackson created an Edwards-type rule, holding that "if police initiate interrogation after a defendant's assertion, at an arraignment or similar proceeding, of his right to counsel, any waiver of the defendant's right to counsel for that police-initiated interrogation is invalid."224

Montejo argued that once counsel had been appointed, the Jackson rule applied and the inculpatory letter of apology had to be suppressed. ${ }^{225}$ The Louisiana Supreme Court disagreed, holding that Jackson protections applied only once a charged defendant affirmatively requested counsel, which Montejo had not done, even though counsel had already been appointed. ${ }^{226}$

The United States Supreme Court resolved this dilemma-whether Jackson applied to any represented defendant, or only to defendants who had requested counsel-by overruling Jackson entirely. ${ }^{227}$ The majority's first step toward overruling Jackson was its conclusion that the Louisiana Supreme Court's "assertion" approach "would lead either to an unworkable standard, or to arbitrary and anomalous distinctions between defendants in different States[,] neither [of which] would be acceptable., ${ }^{228}$ This first step was easy to take, because Montejo, his amicus supporters, and the dissent all agreed that requiring a defendant to affirmatively assert his right to counsel would be an unworkable or arbitrary system. ${ }^{229}$ In a number of other states, "the appointment of

221. 475 U.S. $625,626,635$ (1986).

222. Montejo, 129 S. Ct. at 2082-83.

223. Edwards v. Arizona, 451 U.S. 477, 484-85 (1981).

224. Jackson, 475 U.S. at 636.

225. Montejo, 129 S. Ct. 2082-83.

226. State v. Montejo, 974 So. 2d 1238, 1260-61 (La. 2008) (citing State v. Carter, 664 So. 2d 367, 383 (La. 1995); and Montoya v. Collins, 955 F.2d 279, 282-83 (5th Cir. 1992)). Most jurisdictions had held that Jackson protections applied to any charged defendant for whom counsel had been appointed. See, e.g., Hellum v. Warden, 28 F.3d 903, 909 (8th Cir. 1994); Dew v. United States, 558 A.2d 1112, 1116 (D.C. Cir. 1989); United States ex rel. Espinoza v. Fairman, 813 F.2d 117, 123 n.4 (7th Cir. 1987); Holloway v. State, 780 S.W.2d 787, 795 (Tex. Crim. App. 1989) (en banc).

227. Montejo, 129 S. Ct. at 2091.

228. Id. at 2083.

229. Id. at 2094 (Stevens, J., dissenting); Brief for the United States as Amicus Curiae in Support of Overruling Michigan v. Jackson at 16-17, Montejo, 129 S. Ct. 2079 (No. 07-1529), 
counsel is automatic upon a finding of indigency, . . sua sponte by the court." ${ }^{, 230}$ Given that practice, the majority claimed that the Louisiana Supreme Court's distinction "between defendants who 'assert' their right to counsel and those who do not . . . is exceedingly hazy."231

Having rejected the Louisiana "invocation" rule, the Court also rejected Montejo's proposed rule: that Jackson prohibits the interrogation of any represented defendant, regardless of any "assertion" by the defendant. This approach, the Court reasoned, was "entirely untethered from the original rationale of Jackson," which was to ensure police were prevented "from badgering a defendant into waiving his previously asserted Miranda rights. ${ }^{, 232}$ When a defendant has never asserted that he needs counsel, "there is no basis for a presumption that any subsequent waiver of the right to counsel will be involuntary."233

The Montejo Court's overruling of Jackson has dramatically opened up the doctrinal landscape. It is now unclear whether there is any Edwards-type rule in the Sixth Amendment context for a charged defendant not in custody. Justice Scalia's majority opinion in Montejo provided no explicit reassurances that Edwards has any continuing application in the Sixth Amendment context. In Part III.A of the decision, in which Justice Scalia "emphasiz[ed] first what is not in dispute or at stake here," he mentioned several still-valid Sixth Amendment principles, none of which are an Edwards-type rule. ${ }^{234}$ Later, in Part IV, Justice Scalia again recounted the protections that still exist after the opinion, reciting the Fifth Amendment protections that will be available to at least those defendants being interrogated in custody. ${ }^{235}$ Justice Scalia acknowledged that:

Montejo also correctly observes that the Miranda-Edwards regime is narrower than Jackson in one respect: The former applies only in the context of custodial interrogation. If the defendant is not in custody then those decisions do not apply; nor do they govern other, noninterrogative types of interactions between the defendant and the State (like pretrial lineups). ${ }^{236}$

At this point, Justice Scalia could have assuaged Montejo's (and the defense bar's) concern by stating that an analogous Edwards rule would

\footnotetext{
2009 WL 1019983, at*16-17.

230. Montejo, 129 S. Ct. at 2083 (majority opinion) (citations omitted).

231. Id. at 2084.

232. Id. at 2085 (quoting Michigan v. Harvey, 494 U.S. 344, 350 (1990)) (internal quotation marks omitted).

233. Id. at 2086.

234. Id. at 2085.

235. Id. at 2090.

236. Id.
} 
apply in the Sixth Amendment context once a defendant who has been approached by police invokes his right to counsel, prohibiting police from re-approaching that same defendant. But Justice Scalia did not provide that reassurance. Instead, he explained why Edwards-like protection might be unnecessary for the Sixth Amendment:

[T]hose uncovered situations are the least likely to pose a risk of coerced waivers. When a defendant is not in custody, he is in control, and need only shut his door or walk away to avoid police badgering. And noninterrogative interactions with the State do not involve the 'inherently compelling pressures' that one might reasonably fear could lead to involuntary waivers. ${ }^{237}$

Thus, Edwards is needed in the Fifth Amendment context of the compelling pressures of custodial interrogation because of the captive defendant's unique susceptibility to police badgering. In Sixth Amendment noncustodial interrogation settings, however, neither of these concerns applies.

In sum, the Montejo Court asserted that Jackson was concerned only with the problem of police "badgering" a suspect in custodial interrogation into waiving her rights even though she previously asserted them. The Court also suggested this "badgering" concern might not apply at all in the Sixth Amendment context. The Court trod very carefully in overruling Jackson, with the result that Sixth Amendment interrogation law is now wide open and uncertain.

1. Of "Fair Play" and Badgers: Preventing Police from Asking Suspects to Give Up Previously Invoked Rights

As argued above, Montejo swept away much of Sixth Amendment interrogation law. And Montejo did not replace Jackson with any Edwards-type rule for the Sixth Amendment context, a rule that would prohibit police from continually approaching represented defendants even after they have asserted their rights in the first interrogation attempt. While Montejo carefully sidestepped creating such a rule, the decision also gives some reason to believe the Court may do so at some future point.

Throughout the Court's discussion of why the Jackson rule is unnecessary, the Court at several times noted other rules-such as Edwards-that "prevent police from badgering a defendant into waiving his previously asserted Miranda rights." 238 The Court explained that the Edwards rule, which prohibits police from re-approaching a

237. Id. (citation omitted) (quoting Miranda v. Arizona, 384 U.S. 436, 467 (1966)).

238. Id. at 2085 (quoting Michigan v. Harvey, 494 U.S. 344, 350 (1990)) (internal quotation marks omitted). 
defendant who has previously asserted his right to counsel, "protect[s] a suspect's voluntary choice not to speak outside his lawyer's presence." 239 The Court overruled Jackson in part because the rule did not, like Edwards, simply protect the suspect's own choice. If the defendant (like Montejo himself) had never invoked his right to counsel in the first place, applying the Jackson prohibition was unwarranted:

No reason exists to assume that a defendant like Montejo, who has done nothing at all to express his intentions with respect to his Sixth Amendment rights, would not be perfectly amenable to speaking with the police without having counsel present. And no reason exists to prohibit the police from inquiring. ${ }^{240}$

Notably, the majority's reasoning here echoes that of Justice Kennedy's concurring opinion in Texas $v$. Cobb ${ }^{241}$ (quoted in part above). In Cobb, the Court held that Sixth Amendment interrogation rights are "offense specific." 242 In his concurrence, Justice Kennedy (joined by Justices Scalia and Thomas) cast doubt on Michigan v. Jackson. Justice Kennedy explained that
[I]t is difficult to understand the utility of a Sixth Amendment rule [Michigan v. Jackson] that operates to invalidate a confession given by the free choice of suspects who have received proper advice of their Miranda rights but waived them nonetheless. The Miranda rule and the related preventative rule of Edwards ... . serve to protect a suspect's voluntary choice not to speak outside his lawyer's presence. The parallel rule announced in Jackson, however, supersedes the suspect's voluntary choice to speak with investigators. ${ }^{24}$

Justice Kennedy argued that the Court "ought to question the wisdom of a judge-made preventative rule to protect a suspect's desire not to speak when it cannot be shown that he had that intent."

Thus, Justice Kennedy's concurring opinion in Cobb, like the majority opinion in Montejo, finds its primary fault with Jackson because it may actually interfere with a defendant who is willing to confess to police outside the presence of counsel. For a defendant who has informed police, at the first attempted interrogation, that he only

239. Id. at 2085-86 (quoting Texas v. Cobb, 532 U.S. 162, 175 (2001) (Kennedy, J., concurring)) (internal quotation marks omitted).

240. Id. at 2086-87.

241. 532 U.S. 162 (2001).

242. Id. at 167-68 (quoting McNeil v. Wisconsin, 501 U.S. 171, 175 (1991)).

243. Id. at 174-75 (Kennedy, J., concurring).

244. Id. at 176 . 
wants to speak in counsel's presence, this fault no longer applies. Rather, continued attempts to elicit confessions create the danger that police pressure-badgering, as the Court likes to call it-will induce a defendant to speak when he really wants to rely on counsel.

Throughout Montejo, the Court repeatedly emphasized that the original rationale of Jackson's rule "is to preclude the State from badgering defendants into waiving their previously asserted rights."245 The Court noted that " $t \mathrm{t}]$ he effect of this badgering might be to coerce a waiver, which would render the subsequent interrogation a violation of the Sixth Amendment."246

While the Court spoke carefully in Montejo and did not commit itself to any Edwards-type rule in the Sixth Amendment context, the rhetorical choice of the term "badgering" is itself revealing. One could easily use other terms to describe what police do when they re-approach a suspect, who has previously invoked her rights, to re-ask that suspect to waive her rights. Perhaps the police are simply "asking" the suspect to "reconsider." But the Court in both Shatzer and Montejo repeatedly described this behavior with the pejorative term "badgering." 247 So long as the Court continues to employ the rhetoric of "badgering," it seems likely that the Court will fashion rules limiting or prohibiting the practice.

2. New Rules for "Fair Play" in Sixth Amendment Interrogation Law: Thompkins Will Apply, but Shatzer Will Not

Now that Montejo has cleared away much of the Sixth Amendment doctrinal landscape, several questions arise, in particular whether the Court will apply, in the Sixth Amendment context, various rules it has articulated under the Fifth Amendment. Two doctrines that come to mind are the Thompkins ruling, effectively eliminating any affirmatively "waiver" component to the Miranda "warnings and waiver" regime, and the Shatzer ruling, permitting police to re-approach suspects who have previously invoked their rights after a fourteen-day break in custody. Will the Court apply these doctrines to the Sixth Amendment context? I predict that under the Court's "fair play" approach to interrogation law, the Court will apply Thompkins in the Sixth Amendment context, but will not apply Shatzer.

\section{a. Sixth Amendment Waivers: Thompkins Will Apply}

As noted above, in Berghuis v. Thompkins, the Court held that a

245. Montejo, $129 \mathrm{~S}$. Ct. at 2089. The majority uses the term "badger" (or a variation thereof) ten times in its opinion. See id. at 2085-87, 2089-90.

246. Id. at 2089.

247. Id. at 2085-87, 2089-90; Maryland v. Shatzer, 130 S. Ct. 1213, 1220-21 (2010). 
suspect's inculpatory statement, given after the suspect received and understood the Miranda warnings, constitute a valid waiver of her Fifth Amendment rights. ${ }^{248}$ On its face, Thompkins applies only to the Fifth Amendment, but courts will soon be asked to determine whether the same waiver rule applies to a defendant protected by Sixth Amendment rights rather than Fifth Amendment rights. Using what I have identified as the Court's "fair play" approach to interrogation law, there is every reason to think the Court will apply the Thompkins rule equally in the Sixth Amendment context.

Thompkins makes the most sense if one assumes that the purpose of Miranda is to provide a suspect with "fair notice" of his rights, not to actually dispel the coercion of the interrogation room. ${ }^{249}$ The same logic applies in the Sixth Amendment context. When police seek to interrogate a defendant who has been indicted and is represented by counsel, "fair notice" requires that the police notify the defendant of his rights to remain silent and to speak only in the presence of his attorney. If anything, the Thompkins approach to waiver is easier to justify in the Sixth Amendment context than in the Fifth Amendment context. After all, Fifth Amendment interrogations occur in the unique context of custodial interrogation; Miranda was originally concerned with dispelling the inherent coercion in custodial interrogation. ${ }^{250}$ Sixth Amendment interrogations, in contrast, do not necessarily occur in custody - the Sixth Amendment applies once the suspect has been indicted and is represented by counsel. Thus, the Court has even less concern (perhaps no concern at all) with dispelling potential coercion. As Justice Scalia noted in Montejo:

[Sixth Amendment interrogations] are the least likely to pose a risk of coerced waivers. When a defendant is not in custody, he is in control, and need only shut his door or walk away to avoid police badgering. And noninterrogative interactions with the State do not involve the 'inherently compelling pressures,' that one might reasonably fear could lead to involuntary waivers. ${ }^{251}$

Thus in Thompkins, the Court found that the simple act of speaking was sufficient (given a warning and a presumed understanding thereof) to constitute a waiver of the suspect's Fifth Amendment rights, notwithstanding the inherently compelling pressures of the interrogation room. In the Sixth Amendment context, the Court has noted that those "inherently compelling pressures" are not present, so there is even less

248. Berghuis v. Thompkins, 130 S. Ct. 2250, 2262-63 (2010).

249. See supra Subsection I.A.3.

250. Miranda v. Arizona, 384 U.S. 436, 468 (1966).

251. Montejo, 129 S. Ct. at 2090 (citation omitted) (quoting Miranda, 384 U.S. at 467). 
reason to be concerned that a defendant's choice to speak is involuntary. ${ }^{252}$ In short, the logic of Thompkins applies with even greater force in the context of Sixth Amendment interrogations. Under the Court's "fair play" approach to interrogations, police must inform criminal defendants of their right to remain silent and right to counsel when police approach them outside the presence of counsel. Assuming this "fair notice" has been provided, however, the defendant from then on speaks at his own risk; answers to questions will most likely be deemed to be waivers of his Sixth Amendment rights.

\section{b. Sixth Amendment Invocations: Shatzer Should Not Apply}

In Shatzer $v$. Maryland, the Court created an expiration date for invocations of the Fifth Amendment right to counsel: after a suspect in custodial interrogation invokes her right to counsel, police must cease questioning and cannot re-approach that suspect until fourteen days after release from Miranda custody. ${ }^{253}$ In the context of the Sixth Amendment right to counsel, as opposed to the Fifth Amendment right to counsel at issue in Shatzer, the question of when an Edwards invocation ended never arose. Under Michigan $v$. Jackson, police could not even approach a represented defendant outside the presence of counsel to try to discuss the charged offense, as long as the defendant had asserted his right to counsel. ${ }^{254}$ Most courts interpreted Jackson's prohibition to apply to any represented, charged defendant. ${ }^{255}$ Under that rule, there was no need to ask how "long" an initial invocation lasted: given the rule prohibiting police from approaching a defendant in the first instance, the question of when they might re-approach

252. Id. (quoting Miranda, 384 U.S. at 467).

253. See supra Section I.B.

254. Michigan v. Jackson, 475 U.S. 625, 636 (1986).

255. See United States v. Harrison, 213 F.3d 1206, 1213 (9th Cir. 2000) ("[A] defendant invokes the Sixth Amendment right to counsel as a matter of law when (1) the defendant retains counsel on an ongoing basis to assist with a pending criminal investigation, (2) the government knows, or should know, that the defendant has ongoing legal representation relating to the subject of that investigation, and (3) the eventual indictment brings charges precisely anticipated by the scope of the pre-indictment investigation."); Hellum v. Warden, 28 F.3d 903, 909 (8th Cir. 1994) (stating that for represented, charged defendant, "[t]here is no doubt that Hellum's right to counsel had attached and been invoked prior to his ... subsequent interrogation"); Dew v. United States, 558 A.2d 1112, 1116 (D.C. Cir. 1989) ("[W]e see little, if any, room for an argument that the Supreme Court would permit a police-initiated request for a post-indictment waiver of counsel by a represented defendant, except through defense counsel."); United States ex rel. Espinoza v. Fairman, 813 F.2d 117, 123 n.4 (7th Cir. 1987) (concluding that there was no difference, for purposes of triggering protections, between asserting right to counsel at arraignment versus merely accepting counsel); State v. Boorigie, 41 P.3d 764, 775 (Kan. 2002) (same); Holloway v. State, 780 S.W.2d 787, 795 (Tex. Crim. App. 1989); State v. Dagnall, 612 N.W.2d 680, 695 (Wis. 2000) (defendant "did not have to 'invoke' his Sixth Amendment right to counsel because he ... had an attorney"). 
simply did not arise.

In the wake of Montejo, courts will now be called upon to determine what happens when a charged, represented defendant is approached by police for (noncustodial) interrogation and that defendant invokes the Sixth Amendment right to counsel. One obvious option is to rely on Shatzer and to adopt a fourteen-day break rule before reinterrogation is permitted. For the reasons explained below, this approach should be rejected; there is no reason to create any "expiration date" for invocations of Sixth Amendment rights, because unlike Fifth Amendment invocations, Sixth Amendment invocations are more limited in scope and have a built-in expiration date.

Notwithstanding the similarity between the Fifth Amendment right to counsel (in custodial interrogations) and the Sixth Amendment right to counsel (after the defendant has been charged), the Court has consistently created different rules for these two amendments. Most notably, the Sixth Amendment right to counsel is offense-specific: it applies only to the offense or offenses with which the defendant has actually been charged. ${ }^{256}$ Putting aside Fifth Amendment protections (which apply only in custodial interrogations), the Sixth Amendment right to counsel only protects defendants with respect to the charged crime(s). Police can attempt to interrogate the defendant outside of custody for other uncharged crimes, and need not provide any warnings. And if the defendant invokes her Sixth Amendment right to counsel as to the charged crimes, police can still try to interrogate her for other uncharged crimes. $^{257}$

The Fifth Amendment, in contrast, is not offense-specific: it applies to all police attempts to interrogate a suspect about any offense. Thus, a suspect in custody must be given Miranda warnings before any interrogation, no matter whether the interrogation relates to the crime for which he was taken into custody or for some other possible offense. And when a suspect invokes his Fifth Amendment right to counsel during a custodial interrogation, police cannot attempt to interrogate him about some other matter. ${ }^{258}$

The Shatzer rule was created in response to this unique feature of Fifth Amendment invocations. Because Fifth Amendment rights are not tied to any particular offense, a suspect's invocation of Fifth Amendment rights potentially lasts forever, and as to all crimes: once a suspect has invoked her right to counsel during one custodial interrogation, police are potentially barred from ever attempting to re-

256. Texas v. Cobb, 532 U.S. 162, 167-68 (2001); McNeil v. Wisconsin, 501 U.S. 171, 175 (1991).

257. Cobb, 532 U.S. at $173-74 ;$ McNeil, 501 U.S. at 178 .

258. Minnick v. Mississippi, 498 U.S. 146, 153 (1990); Arizona v. Roberson, 486 U.S. 675, 683-84 (1988); Edwards v. Arizona, 451 U.S. 477, 484-86 (1981). 
interrogate her, even about some wholly unrelated crime years later. Without some "expiration" of the sort created in Shatzer, Justice Alito's extreme hypothetical could occur: a suspect who invoked his right to counsel in Maryland in a 1999 interrogation for suspected joy riding could not be questioned in 2009 for a murder in Montana. ${ }^{259}$

Because the Sixth Amendment right to counsel does not share this feature of Fifth Amendment law, no Shatzer-type expiration rule is required. In the Sixth Amendment context, a defendant's invocation of the right to counsel does not prohibit any future police interrogation; it merely prohibits future police interrogation related to the specific offense or offenses with which the defendant has already been charged. This means the invocation is limited in both scope and time.

First, as to scope, the invocation only applies to the charged offenses. If police want to ask the defendant about uncharged offenses, they are free to do so, even after the defendant has invoked her Sixth Amendment rights.

Second, as to time, the invocation of Sixth Amendment rights is limited by the natural life of the existing criminal prosecution. Once the defendant is either convicted (through a guilty plea or conviction after trial) or acquitted, the Sixth Amendment prohibition presumably ends; because the prohibition is tied to the pending offense, once the offense is no longer pending, the prohibition also disappears.

Thus, in the Sixth Amendment context, the Shatzer fourteen-day rule is a solution in search of a problem. In the Sixth Amendment context, there is no "eternal invocation" problem: the invocation of the right to counsel only applies to the offense charged, and that prohibition ends once the charged offense is terminated through conviction, acquittal, or dismissal of charges.

In addition to being unnecessary, the Shatzer rule is also undesirable in the Sixth Amendment context. The Shatzer rule states that police may re-approach a suspect who has invoked his right to counsel fourteen days after a release from Miranda custody. ${ }^{260}$ In the Sixth Amendment context, the suspect need not even be in custody in the first place. Thus, the Shatzer rule would turn into a simple fourteen-day rule: once a represented defendant invokes his right to counsel, police may reapproach him fourteen days later to again attempt to interrogate him outside the presence of counsel. Because the defendant need not be in "custody," that part of Shatzer no longer applies. Assuming the Court creates any type of Edwards protection for the Sixth Amendment context-any rule prohibiting police from badgering a defendant into reneging on her previous invocation of the right to counsel--it would be

259. Shatzer Transcript, supra note 116, at 31-32.

260. Maryland v. Shatzer, 130 S. Ct. 1213, 1223 (2010). 
strange to place a two-week expiration date on that protection. Once a criminal suspect has been charged and become a criminal defendant, his need for counsel's assistance is heightened. ${ }^{261}$ In that context, a defendant who tells police, upon being approached for interrogation, that he wants to deal with them only through counsel, should be protected against any further police badgering.

Thus, the Shatzer fourteen-day rule is both unnecessary and undesirable in the context of Sixth Amendment invocations. Unlike Thompkins, which likely applies in the Sixth Amendment context as well as the Fifth, Shatzer should be limited to the Fifth Amendment context in which it is needed.

\section{THE "FAIR Play" Model: FaUlty Premises MAKe FOR BAD DOCTRINE}

Parts I and II described how the Roberts Court interrogation decisions are reshaping both Fifth and Sixth Amendment interrogation rules toward the underlying principle of "fair play" in interrogations. Part III evaluates that change.

The core problem with the Roberts Court's "fair play" principle is that, as the Court applies it in the cases discussed herein, it presupposes an interrogation suspect who is autonomous, competent, and empowered to protect his interests. The "fair play" model represents a rejection of the Warren Court's description of the problem: that individuals undergoing police interrogation face inherent compulsions that threaten to "exact[] a heavy toll on individual liberty and trade[] on the weakness of individuals." 262 The Warren Court's solution to this problem, in the form of the Miranda and Massiah rules for interrogation, have been long criticized from both the right and the left. ${ }^{263}$ But the diagnosis itself - that suspects facing police interrogation are vulnerable to abuse and overreaching - has proven robust, supported by a growing body of experiential and empirical research. ${ }^{264}$ Thus, the Roberts Court's "fair play" principle for interrogation, which presupposes autonomous suspects who do not need protection from inherent pressures, does not match the state of the evidence.

First, the ongoing trend of DNA exonerations by convicts, including a number who falsely confessed to their crimes, has proven that suspects in interrogation are more susceptible to false confession than

261. This is evident from, among other things, the fact that the Sixth Amendment right to counsel mandates governmental provision of counsel after the defendant has been charged, but not before. See Brewer v. Williams, 430 U.S. 387, 398 (1977); Gideon v. Wainwright, 372 U.S. 335,344 (1963).

262. Miranda v. Arizona, 384 U.S. 436, 455, 458 (1966).

263. See supra note 17.

264. See supra notes 34-36 and accompanying text. 
had previously been thought possible. ${ }^{265}$ Many people, including judges and jurors, have long shared a commonsense belief that an innocent person would not confess to a serious crime except under circumstances of extreme duress, such as prolonged torture. ${ }^{266}$ Repeated exonerations - either by DNA or by the identification of the true guilty party-of convicts who confessed to serious crimes show that this commonsense belief is inaccurate, and false confessions are more common than we intuitively would guess. ${ }^{267}$ Thus, " $[t]$ here is a new awareness among scholars, legislators, courts, prosecutors, police departments, and the public that innocent people falsely confess, often due to psychological pressure placed upon them during police interrogations."268 The Roberts Court's "fair play" rules presuppose that suspects in interrogation are autonomous agents capable of looking out for their own interests, not inherently vulnerable to police pressures. That is to say, the "fair play" rules reflect the commonsense belief that innocent persons would not falsely confess except under extreme duress, and thus do not need any special protections from police pressures. Mounting evidence shows this commonsense belief is false, and re-affirms the Warren Court's assumption that suspects in interrogation are more vulnerable to police pressure than many of us intuitively believe.

Second, empirical psychological studies have provided coherent explanations for this phenomenon. Professor Brandon L. Garrett explains that "[s]cholars increasingly study the psychological techniques that can cause people to falsely confess and have documented how such techniques were used in instances of known false confessions.",269 Indeed, "psychologists have known that people are highly responsive to reinforcement and subject to the laws of conditioning, and that behavior is influenced more by perceptions of

265. See Steven A Drizin \& Richard A. Leo, The Problem of False Confessions in the Post-DNA World, 82 N.C. L. REv. 891, 904-06 (2004) ("[S]tudies report that the number of false confessions range from $8-25 \%$ of the total miscarriages of justices studied, thus establishing the problem of false confessions as a leading cause of wrongful convictions of the innocent in America.").

266. This commonsense belief is typified by John Henry Wigmore's claim that false confessions were "scarcely conceivable," "of the rarest occurrence," and that "[n]o trustworthy figures of authenticated instances exist...." 2 JOHN HENRY WIGMORE, A TREATISE ON THE ANGLO-AMERICAN SYSTEM OF EVIDENCE IN TRIALS AT COMMON LAW $§ \S 835,867$ (2d ed. 1923); see also Saul M. Kassin et al., Police-Induced Confessions: Risk Factors and Recommendations, 34 LAW \& HuM. BeHAV. 3, 6, 24 (2010) ("[M]ost people reasonably believe that they would never confess to a crime they did not commit and have only rudimentary understanding of the predispositional and situational factors that would lead someone to do so.").

267. See Drizin \& Leo, supra note 265 , at 904-06.

268. Brandon L. Garrett, The Substance of False Confessions, 62 STAN. L. REV. 1051, 1052-53 (2010).

269. Id. at 1053. 
short-term than long-term consequences." ${ }^{270}$ Additionally, psychologists have determined "that individuals are highly vulnerable to influence from change agents who seek their compliance." ${ }^{271}$ In particular, suspects in interrogation are vulnerable to identified psychological tools relating to "attitudes and persuasion, informational and normative influences, the use of sequential request strategies, ... and the gradual escalation of commands, issued by figures of authority, to effectively obtain self- and other-defeating acts of obedience."272 Custodial interrogation exploits established psychological problems with "memory transience, misattribution effects, suggestibility, and bias." 273

In short, the Roberts Court's presumption that suspects in interrogation are autonomous agents capable of protecting their own interests is wrong. The resulting rules of "fair play" in interrogation fail to adequately protect the constitutional right against self-incrimination and the guarantee of the assistance of counsel in all criminal cases. If one accepts the premise that the privilege against compelled selfincrimination applies to custodial interrogation, then the Roberts Court's refusal to acknowledge the serious compulsions inherent in custodial interrogation is wrongheaded. The Court has offered no convincing rebuttal of that basic premise; it has just slowly and steadily marginalized it.

The Court's model "works" only by presupposing a population that approaches the police with an attitude of suspicion and contempt, rather than respect and reasonable deference. If the population exhibits the attitude toward the police that the Court would likely expect and desire-namely an attitude of respect and reasonable deference to authority-then the Court's model will result in that population consistently and predictably making poor choices in custodial interrogation, and succumbing to the inherent pressures of the interrogation room. Ironically, recent studies have suggested that "innocence itself may put innocents at risk." 274 This happens because "people who stand falsely accused tend to believe that truth and justice will prevail and that their innocence will become transparent to investigators, juries, and others[,]" and thus, such innocents "cooperate fully with police, often failing to realize that they are suspects not witnesses." 275

If the Court's "fair play" principle rests on unrealistic assumptions

270. Kassin et al., supra note 266 , at 15.

271. Id.

272. Id. (citations omitted).

273. Id.

274. Id. at 22 (citing Saul M. Kassin, On the Psychology of Confessions: Does Innocence Put Innocents at Risk?, 60 AM. PsYchologisT 215, 223-24 (2005)).

275. Id. at 22-23 (citing Kassin, supra note 266, at 224). 
about human behavior in interrogation, why is the Court shaping interrogation law along these misguided lines? The "fair play" model allows the Court to shape Miranda and related interrogation rules to facilitate police interrogation and the use of confessions in criminal cases, by providing a "safe harbor" for police. ${ }^{276}$ So long as police satisfy the requirements of the Court's relatively clear and policefriendly interrogation rules, police interrogation techniques will not be overly scrutinized, and the resulting confession will very likely be admissible.

By reformulating the Miranda rules under the "fair play" rubric, the Roberts Court has made it much easier for police to reach that safe harbor. Through Powell, which required only "fair notice" of rights rather than clear evidence that the suspect comprehends and appreciates her rights, the Court imposed a relatively simple requirement on police (recite some version of the warnings) instead of the more difficult task of ensuring that a possibly uneducated, scared, defensive, or confused suspect truly comprehends her rights in the interrogation setting. Through Thompkins, the Court removed a barrier that might prevent police from reaching the Miranda safe harbor, by eliminating the requirement that police elicit a distinct waiver from the suspect separate from and before any admissible confession. Thus, Thompkins makes the "safe harbor" less dependent on what the suspect does or fails to do, and more within the exclusive realm of police following the required procedures.

Shatzer limited the damage to police interrogation done by a suspect's successful invocation of the right to counsel, by allowing police to return after a fourteen-day break in Miranda custody. The majority created for police a clear (and not very onerous) time limitation of two weeks, permitting police to again try to reach the Miranda safe harbor. The majority was wholly unconcerned with Justice Stevens' objection that by failing to actually provide the suspect with counsel during that two-week period, the police have effectively misled the suspect and potentially caused the suspect to understand that her rights are illusory. ${ }^{277}$ The suspect is told, "You have a right to a lawyer during

276. See FrIED, supra note 9, at 45 ("[M]ost professional law-enforcement organizations had learned to live with Miranda, and even to love it, to the extent that it provided them with a safe harbor...."); Klein, supra note 9, at 1033 ("[A] 'constitutional safe harbor rule' is a judicially created procedure that, if properly followed by the government actor, insulates the government from the argument that the constitutional clause at issue was violated.").

277. Maryland v. Shatzer, 130 S. Ct. 1213, 1225 (2010); id. at 1229 (Stevens, J., concurring in the judgment) ("When police tell an indigent suspect that he has the right to an attorney, that he is not required to speak without an attorney present, and that an attorney will be provided to him at no cost before questioning, the police have made a significant promise. If they cease questioning and then reinterrogate the suspect 14 days later without providing him with a lawyer, the suspect is likely to feel that the police lied to him and that he really does not 
this interrogation." The suspect responds, "Okay, I want a lawyer during my interrogation." Police then leave, and no lawyer is provided - even if the suspect keeps asking his jailers, "Can I get a lawyer? The cops told me I could have one." Two weeks later, police again show up, without a lawyer, and ask to interrogate the suspect, again warning him that he has a right to a lawyer - the same right he previously invoked, and the same request which did not result in a lawyer being provided. The reasonable message received by the unsophisticated inmate could well be that the promise of a lawyer is illusory and that police will recite certain warnings but not follow through on their promises. ${ }^{278}$

The point here is that the majority's rule in Shatzer is simply not designed to ensure that a suspect understands her rights and is sufficiently empowered to protect those rights during the custodial interrogation. Rather, the rule created clear, easily met rules that police can follow to reach the Miranda safe harbor.

The Sixth Amendment rules, after Montejo, are far less clear than the Fifth Amendment rules; thus, it is more difficult to make definitive evaluations of the Court's approach-much of its approach remains to be seen. At a minimum, Montejo's overruling of Michigan v. Jackson begins to create space for police to successfully interrogate charged, represented defendants. Montejo gives the Court the space to craft "safe harbor" rules for police-initiated interrogation in the Sixth Amendment context, as it has done in the Fifth Amendment context. Whether the Court will actually do so remains to be seen.

In Ventris, the Court clarified that when police violate the Sixth Amendment interrogation rules (the content of which are still largely uncertain), the violation occurs at the time of interrogation, not when the statement is later used at trial. Rather than create a "safe harbor" rule, the Court in Ventris continued its trend of reducing the consequences for police when they do violate constitutional interrogation rules-thereby permitting some use of confessions obtained in violation of the Sixth Amendment.

If the Roberts Court's "fair play" rules are flawed, what interrogation rules should the Court be creating? The central flaw in the Roberts Court approach to interrogation is that it rests on faulty assumptions about how suspects behave in interrogations. The best way forward is to create interrogation rules based on what current research tells us about interrogation. A good start is articulated by Professor Saul

have any right to a lawyer.").

278. The sophisticated suspect will realize that the warning, "You have a right to an attorney during this interrogation," really means, "If you tell us you want a lawyer, we will stop interrogating you," - not that a lawyer will in fact be provided. But of course the latter message - that the right to a lawyer is instead, in practice, the right to terminate the interrogation--is not part of the required Miranda warnings. 
M. Kassin and his co-authors in their recent article, Police-Induced Confessions: Risk Factors and Recommendations. ${ }^{279}$ Those recommendations include:

1. Videotape custodial interrogations: "all custodial interviews and interrogations of felony suspects should be videotaped in their entirety and with a camera angle that focuses equally on the suspect and interrogator."

2. Shift from a "confrontational" model of interrogation - where guilt is presumed and the sole aim is to elicit a confession-to an "investigative" model of interrogation-where police do not presume guilt but instead seek to obtain information about crimes. 3. Limit the time a suspect is interrogated and held in
isolation.

4. Ban or limit police ability to lie or present false evidence to a suspect in interrogation, given research indicating "that outright lies can put innocents at risk to confess by leading them to feel trapped by the inevitability of evidence against them."

5. Ban or more strictly regulate the strategy of "minimization"-in which police imply leniency for a suspect who confesses - in light of research showing "that implicit promises can put innocents at risk to confess by leading them to perceive that the only way to lessen or escape punishment is by complying with the interrogator's demand for confession.

279. Kassin et al., supra note 266.

280. Id. at 25 (emphasis omitted).

281. Id. at $27-28$.

282. Id. at 28.

283. Id. at 28-29 (noting evidence of this problem consists of: "(1) the aggregation of actual false confession cases, many of which involved use of the false evidence ploy; (2) one hundred-plus years of basic psychology research, which proves without equivocation that misinformation can substantially alter people's visual perceptions, beliefs, motivations, emotions, attitudes, memories, self-assessments, and even certain physiological outcomes, as seen in studies of the placebo effect; and (3) numerous experiments, from different laboratories, demonstrating that presentations of false evidence increase the rate at which innocent research participants agree to confess to prohibited acts they did not commit.").

284. Id. at 29-30 (evidence of this problem consists of: "(1) the aggregation of actual false confession cases, the vast majority of which involved the use of minimization or explicit promises of leniency; (2) basic psychological research indicating, first, that people are highly responsive to reinforcement and make choices designed to maximize their outcomes, and second that people can infer certain consequences in the absence of explicit promises and threats by pragmatic implication; and (3) experiments specifically demonstrating that minimization 
6. Protect particularly vulnerable suspects, such as "juveniles and people who are cognitively impaired or psychologically disordered." 285

The central purpose of this Article is to identify the underlying principle driving the Roberts Court's reshaping of constitutional interrogation law, not to articulate the best set of interrogation rules a court or legislature could create. Therefore, while the suggestions above from a group of experts are certainly a good start, my purpose is not to fully endorse any particular set of rules.

\section{CONCLUSION}

The Roberts Court's constitutional interrogation decisions show hostility towards the Warren Court's deep concern for protecting vulnerable suspects from the coercion of interrogation. Instead, the Roberts Court is reshaping interrogation rules toward the concept of "fair play" in interrogations, a rubric which presupposes interrogation suspects as autonomous agents capable of actively protecting their own interests and expected to do so. This underlying assumption, however, is unfounded and inconsistent with a steadily growing body of experience (in the form of DNA exonerations of convicts who confessed) and empirical research. Because the Court's foundational premise is wrong, its resulting rules of "fair play" in interrogation fail to adequately protect the constitutional right against self-incrimination and the guarantee of the assistance of counsel in criminal cases. 
